\title{
Disposable Workers: Applying a Human Rights Framework to Analyze Duties Owed to Seriously Injured or III Migrants
}

Lori A. Nessel

Seton Hall University School of Law, lori.nessel@shu.edu

Follow this and additional works at: https://www.repository.law.indiana.edu/ijgls

Part of the Human Rights Law Commons, International Law Commons, and the Labor and Employment Law Commons

\section{Recommended Citation}

Nessel, Lori A. (2012) "Disposable Workers: Applying a Human Rights Framework to Analyze Duties Owed to Seriously Injured or III Migrants," Indiana Journal of Global Legal Studies: Vol. 19 : Iss. 1 , Article 3.

Available at: https://www.repository.law.indiana.edu/ijgls/vol19/iss1/3

This Symposium is brought to you for free and open access by the Law School Journals at Digital Repository @ Maurer Law. It has been accepted for inclusion in Indiana Journal of Global Legal Studies by an authorized editor of Digital Repository @ Maurer Law. For more information, please contact rvaughan@indiana.edu.

\section{$\Psi$}

JEROME HALL LAW LIBRARY

INDIANA UNIVERSITY

Maurer School of Law
Bloomington 


\title{
Disposable Workers: Applying a Human Rights Framework to Analyze Duties Owed to Seriously Injured or Ill Migrants
}

\author{
LORI A. NESSEL ${ }^{*}$
}

\begin{abstract}
The practice of medical repatriation, or the extrajudicial deportation of seriously ill immigrants directly by hospitals, was largely unknown and under-theorized until recently. In the past few years, a number of scholars have focused on the legal and ethical issues raised by this practice. However, medical repatriation has most often been analyzed in isolation as an example of an anomalous unlawful or unethical action undertaken by hospitals, rather than as a predictable, if horrifying, extension of a legal regime that treats migrant labor as disposable.

In contrast, this Article contextualizes the private deportation of migrant workers by hospitals within broader themes of globalization, undocumented labor migration, and increasing privatization of immigration enforcement functions. In contrasting the humanitarian aspects of the United States' approach to protecting victims of human trafficking, violent crimes, and domestic violence with the punitive approach taken toward migrant laborers, this Article attempts to deconstruct the widely held belief, as expressed in laws and policies, that the United States or other countries that rely on migrant workers owe nothing in return for the labor that is provided.

* Professor of Law and Director, Center for Social Justice, Seton Hall University School of Law. My thinking about the practice of medical repatriation and the human rights implications has benefitted greatly from collaborative work on the issue with a number of colleagues including Rachel Lopez and Anjana Malhotra at Seton Hall Law and Nisha Agarwal and Shena Elrington of NYLPI's Health Justice Program. Clinical law students Todd Tolin and Erica Sibley also helped to develop and draft human rights arguments to challenge the practice of medical repatriation. Thanks also to Anthony Liberatore and Stephanie Duque for invaluable research assistance and, as always, to John for guidance and input. Finally, I am grateful to the faculty and students that organized and participated in the Globalization and Migration symposium and especially to Nathalie Peutz for her comments on an earlier draft of this paper.
\end{abstract}

Indiana Journal of Global Legal Studies Vol. 19 \#1 (Winter 2012)

(c) Indiana University Maurer School of Law 


\section{INTRODUCTION}

At the time of his tragic accident, Quelino Ojeda Jimenez was a twenty-year-old Mexican migrant laborer who had been engaged in construction work in the United States for four years. While working on a roof in Chicago, Quelino fell backwards and plummeted over twenty feet to the ground below. Comatose for three days, he awoke at Advocate Christ Hospital, nearly quadriplegic and reliant on a ventilator in order to breathe. Although the hospital treated him for four months, it could not seek reimbursement for the ongoing medical care because of Quelino's undocumented immigration status. Shortly before Christmas, without notifying the Mexican Consulate or obtaining Quelino's consent, the hospital ushered him onto a private plane and flew him to a hospital in Mexico that lacked the equipment required to sustain his life. ${ }^{1}$ After languishing for more than a year in a rural hospital in Mexico that was ill equipped to handle his needs, twenty-one-year-old Quelino Ojeda Jimenez passed away on January 1, 2012.2

Charlie Deeyu is a twenty-eight-year-old Burmese migrant worker who found himself chained to a hospital bed in Thailand after a severe work injury on a construction site left him immobilized and in need of treatment. According to the Thai immigration authorities, Deeyu's immigration status warranted that he be shackled to his hospital bed as a flight risk, notwithstanding that the work injury had left him immobilized. ${ }^{3}$

Maria Sanchez was being prepped for surgery at the University of Texas Medical Branch's John Sealy Hospital to remove a banana-sized tumor that was causing loss of movement in her limbs when she was suddenly discharged and told to "go to Mexico."4

1. Judith Graham et al., Undocumented Worker Who Became Quadriplegic Is Moved to Mexico Against His Will, CHI. TRIB., Feb. 6, 2011, http://articles.chicagotribune.com/ 2011-02-06/news/ct-met-quadriplegic-immigrant-deporte20110206_1_advocate-healthcare-ojeda-mexican-hospital.

2. Becky Shlikerman, Quadriplegic Immigrant Dies After Chicago-Area Hospital Returned Him to Mexico, CHI. TRIB., Jan. 4, 2012, http://articles.chicagotribune.com/201201-04/health/ct-met-quelino-death-20120104_1_quelino-ojeda-jimenez-mexican-familymexican-hospital.

3. Joseph Allchin, Migrant 'Was Chained to Hospital Bed', DEM. VolCE BURMA, Feb. 4, 2011, http://www.dvb.no/news/migrant-was-chained-to-hospital-bed'/14082; Press Release, Human Rights \& Dev. Fund., THAILAND: Rights Grps. to Request Thai Nat'l Police Chief to Unchain Injured Migrant Work Accident Victim from Myan. Detained Pending Deportation, (Feb. 4, 2011), available at http://www.humanrights.asia/news/forwardednews/AHRC-FST-007-2011.

4. Harvey Rice, Illegal Immigrant's Ouster at Galveston Hospital Raises Questions, Hous. CHRON., Feb. 7, 2011, http//www.chron.com/disp/story.mpl/metropolitan/7416070.html. 
Throughout the world, migrant workers perform the most hazardous work for the lowest wages. ${ }^{5}$ However, when migrant workers or their family members are injured or become seriously ill and require ongoing medical treatment, they find themselves at the intersection of two unforgiving regimes: immigration and health care. In the United States, hospitals that receive federal Medicare funding are required to provide emergency treatment regardless of immigration status. ${ }^{6}$ However, once an undocumented patient is stabilized, the federal government ceases to pay for ongoing necessary medical care in hospitals or in rehabilitation facilities. ${ }^{7}$

Congress's decision to deny reimbursement to hospitals and nursing homes for treatment of undocumented patients has left a dangerous void between the moral and human rights-based duty to care for the sick and the economic pressure to avoid costly ongoing treatment for patients that are not able to afford it or to qualify for governmental reimbursement programs. ${ }^{8}$ In an effort to save costs, and within the

5. See, e.g., Pia M. Orrenius \& Madeline Zavodny, Do Immigrants Work in Riskier Jobs? 19-20 (Fed. Reserve Bank of Dall. Research Dep't, Working Paper No. 0901, 2009), available at http://www.dallasfed.org/research/papers/2009/wp0901.pdf (examining injury and fatality rates in employment patterns of natives and immigrants and concluding that immigrants work in more dangerous industries and occupations than do their native born counterparts); Worker Abuse: Latino Workers in the South Face Rampant Abuse, S. POVERTY L. CTR., http://www.splcenter.org/publications/under-siege-life-low-incomelatinos-south/1-worker-abuse (last visited Jan. 15, 2012) (discussing the hazardous working conditions immigrants face in the United States, and citing that overall, thirty two percent of Latinos surveyed reported on-the-job injuries); RANDY CAPPS ET AL., URB. InST., A PROFILE OF THE LOW-WAGE IMMIGRANT WORKFORCE 1 (2003), available at http://www.urban.org/UploadedPDF/310880_lowwage_immig_wkfc.pdf (noting key findings including that: (1) immigrants comprise 11 percent of all U.S. residents, but 14 percent of all workers and 20 percent of low-wage workers; and (2) immigrants' hourly wages are lower on average than those of natives, and nearly half earn less than 200 percent of the minimum wage, as compared with one-third of native born workers); see also Sarah H. Paoletti, Transnational Responses to Transnational Exploitation: A Proposal for Bi-national Migrant Rights Clinics, 30 U. PA. J. INT'L L. 1171, 1171 (2009) (noting that migrant workers are engaged in low-wage employment in all parts of the world that is characterized as "dirty, dangerous, and degrading").

6. Pursuant to the Emergency Medical Treatment and Leave Act (EMTALA), all hospitals receiving federal Medicare funds are required to provide emergency care to all patients, regardless of immigration status. See 42 U.S.C. $\$ 1395 \mathrm{dd}(\mathrm{B})(1)(\mathrm{A})$-(B) (2011); see also Brietta R. Clark, The Immigrant Health Care Narrative and What it Tells Us About the U.S. Health Care System, 17 ANN. HEALTH L. 229, 238 (2008).

7. See 42 U.S.C. $\S \S 1395 \mathrm{dd}(\mathrm{c}),(\mathrm{e})(3)(\mathrm{A})$; Condition of Participation: Discharge Planning, 42 C.F.R. $\$ 482.43$ (2011).

8. Congress has also made a policy choice to exclude even lawful permanent residents from Medicare benefits for five years. See Personal Responsibility and Work Opportunity Reconciliation Act of 1996, 8 U.S.C. $\$ 1601$ (2011). Moreover, undocumented immigrants 
broader context of the privatization of immigration regulation and increasing immigration enforcement by local actors, many public and private hospitals take it on themselves to enforce the nation's immigration laws by deporting desperately ill immigrants directly from their hospital beds. ${ }^{9}$ In this new frontier of privatized immigration enforcement, hospitals act unilaterally or in concert with private transport companies to deport seriously ill or catastrophically injured migrants.

When viewed from an immigration perspective, the undocumented immigrant in need of medical care is often characterized as a lawbreaker, and the hospital's private deportation is seen as returning the migrant to the position he would have been in had he not broken the law and entered the United States without permission. Viewed from a healthcare perspective, the prevailing focus is on the unjust cost to the hospital and taxpayer, with the migrant's claim to medical treatment seemingly detached from the gritty reality that he was injured or became ill while working in the host country. The immigrant is viewed as an "outsider" who belongs in his home country and, instead, unreasonably demands costly treatment abroad.

While the practice of medical repatriation, or the extrajudicial deportation of seriously ill immigrants directly by hospitals, had been largely unknown and undertheorized until recently, in the past few years, a number of scholars have focused upon the legal and ethical issues raised by this practice. ${ }^{10}$ However, medical repatriation has most often been analyzed in isolation as an example of an anomalous

are precluded from purchasing health care insurance pursuant to the Patient Protection and Affordable Care Act, 42 U.S.C. $§ 18081(\mathrm{a})(1)$ (2011).

9. This practice is most often termed either "medical repatriation," "hospital repatriation," or "medical deportation." Although there are some patients that seek to be repatriated to their native countries, my focus in this article is on the cases that involve forced or coerced medical repatriations.

10. See, e.g., Lori A. Nessel, The Practice of Medical Repatriation: The Privatization of Immigration Enforcement and Denial of Human Rights, 55 WAYNE L. REV. 1725 (2009) (arguing that forced or coerced medical repatriations violate the immigrant's right to due process and life and pose ethical dilemmas and concluding that reform of the United States' immigration and health care regimes are essential); Caitlin O'Connell, Return to Sender: Evaluating the Medical Repatriations of Uninsured Immigrants, 87 WASH. U. L. REV. 1429, 1458.59 (2010) (arguing that medical repatriations jeopardize the repatriated patient's health and expose the hospital to potential liability thus failing to benefit either the hospital or the undocumented worker); Joseph Wolpin, Medical Repatriation of Alien Patients, 37 J. L. MED. \& ETHICS 152 (2009) (noting that immigration and Medicaid reforms over the past decade have created a de facto regulatory framework in which repatriation has become an attractive solution for hospitals faced with increasing costs of uncompensated medical care for uninsured noncitizens and arguing for a regulatory framework that would protect undocumented workers' rights). 
unlawful or unethical action undertaken by hospitals, rather than as a predictable, if horrifying, extension of a legal regime that treats migrant labor as disposable.

In this Article, I examine the relationship between the private deportation of migrant workers by hospitals with broader themes of globalization, undocumented labor migration, and increasing privatization of immigration enforcement functions. I also examine the practice of medical repatriation as an example of the broader need for a human rights-based approach to migration and particularly to the treatment of undocumented workers. I seek to explore the interconnectedness between migration patterns that are based on the demand in industrialized countries for workers to engage in low-paid, hazardous work and the way in which the migrant workforce is perceived as not being entitled to basic human rights protections. By utilizing a human rights-based framework, I critique the practice of medical repatriations. In contrasting the humanitarian aspects of the United States' approach to protecting victims of human trafficking with the punitive approach taken towards migrant laborers, I attempt to deconstruct the widely held belief, as expressed in laws and policies, that the United States or other countries that rely on migrant workers owe nothing in return for the labor that is provided.

\section{DEFINING THE SCOPE AND FREQUENCY OF MEDICAL REPATRIATIONS}

Because the practice of medical repatriation takes place in the shadows without any governmental regulation, it is impossible to know exactly how many patients are unwillingly deported by U.S. hospitals. ${ }^{11}$ However, for the past year, faculty and students at Seton Hall University School of Law's Center for Social Justice have been documenting attempted and actual cases of coerced or nonconsensual deportations by hospitals throughout the United States. The evidence collected to date clearly establishes that medical repatriations are occurring with alarming frequency in publicly and privately owned hospitals across the United States. ${ }^{12}$ For example, there have been

11. In a New York Times series on medical repatriation, Deborah Sontag characterized the practice as "little-known but apparently widespread" noting that "[m]edical repatriations are happening with varying frequency, and varying degrees of patient consent, from state to state and hospital to hospital. No government agency or advocacy group keeps track of these cases, and it is difficult to quantify them." See Deborah Sontag, Immigrants Facing Deportation By U.S. Hospitals, N.Y. TimES, Aug. 3, 2008, at A1.

12. "Overall, the [Center for Social Justice], [New York Lawyers for the Public Interest], [Border Action Network], and Law Offices of Chavez \& De León, P.A., have been able to document more than 100 cases of extrajudicial forced or coerced medical repatriation in the United States." Letter from Lori Nessel, Faculty Dir., Ctr. Soc. Justice 
reported cases of patients being unwillingly repatriated from hospitals in New York, ${ }^{13}$ Michigan, ${ }^{14}$ New Jersey, ${ }^{15}$ Maryland, ${ }^{16}$ Arizona, ${ }^{17}$ Illinois, ${ }^{18}$ and Florida ${ }^{19}$ to Mexico, Guatemala, Honduras, and other countries. ${ }^{20}$

In some instances, hospitals exert undue pressure on families of critically injured immigrants, threatening to remove their loved ones from the country with or without their permission. ${ }^{21}$ Even in cases in which the immigrant patient has long-standing ties to the United States and might be eligible for lawful immigration status, hospitals have threatened imminent removal and failed to advise as to the immigration options available or the consequences of removal. ${ }^{22}$ In other cases, the hospitals have acted without obtaining consent and against the wishes of family members. For example, in one documented case, the hospital

et al., to Dr. Santiago Canton, Exec. Sec'y, Inter-Am. Comm'n on Human Rights (Feb. 2, 2011), available at http://aw.shu.edu/ProgramsCenters/PublicIntGovServ/CSJ/upload/ Seton_Hall_Request_for_Hearing_on_Medical_Repatriation-fnl.pdf.

13. Nisha Agarwal \& Liane Aronchick, A Matter of Life and Death: Advocates in New York Respond to Medical Repatriation, 46 HARV. C.R.-C.L. L. REV. (forthcoming 2011), available at http:/harvardcrcl.org/wp-content/uploads/2011/02/Agarwal_Aronchick_Matter_ of_Life.pdf (last visited Jan. 26, 2012).

14. See Case of Jose G., documented by the Ctr. for Soc. Justice (on file with author).

15. See Case of Enrique L., documented by the Ctr. for Soc. Justice (on file with author).

16. See Case of Manuel L., documented by the Ctr. for Soc. Justice (on file with author).

17. See Deborah Sontag, Getting Tough: Deported in a Coma, Saved Back in U.S., N.Y. TIMES, Nov. 8, 2008, at A1 (discussing the case of Antonio Torres).

18. See Colleen Mastony, For Patient, Time Runs Out, CHI. TRIB., Nov. 9, 2005, http://articles.chicagotribune.com/2005-11-09/news/0511090305_1_nursing-long-term-carepatient (discussing the case of Orlando Lopez).

19. See Nessel, supra note 10, at 1724-31(discussing the case of Luis Alberto Jimenez).

20. See, e.g., SETON HALL UNIV. Sch. L. CTR. FOR SOC. JUST. \& N.Y. LAW. FOR PUB. INT., SUBMisSion to THE UNITED NATIONS HUMAN RIGHTS COUNCIL AS PART OF ITS UNIVERSAL. PERIODIC REVIEW REgaRding THE EXTRAJUdICLAL INVOLUNTARY DEPORTATIONS OF IMMIGRANT PATIENTS BY U.S. HOSPITALS, If 2, 5, http://lib.ohchr.org/HRBodies/ UPR/Documents/session9/US/SHUSL_SetonHallUniversitySchool.pdf.

21. For example, a federally funded public hospital in Arizona repatriated a nineteenyear-old gunshot victim to Mexico, immediately after surgery and against the wishes of her family. She arrived in Mexico in poor condition and died the next day from septic shock. See Case of Anonymous (on file with author) (name omitted for privacy).

22. Id. In this case, the young woman had resided in the United States since she was one-year-old and had a close relative with lawful permanent resident status. Pursuant to U.S. immigration law, she might have qualified for family-based immigration or discretionary relief from removal. See, e.g., Immigration and Nationality Act, 8 U.S.C. $\S$ 1153(a) (2011) (providing for visas for particular family-based immigrants); 8 U.S.C. 1229 (b) (allowing for the cancellation of removal and adjustment of status of certain nonpermanent residents). 
acted against the family's wishes, flew a critically injured immigrant to Guatemala, and left him on the tarmac. ${ }^{23}$

While most of the forced or coerced repatriations involve patients that lack lawful immigration status, lawful permanent residents have also been subjected to this practice. For example, in one case, a ninèteen-year-old U.S. lawful permanent resident was critically injured in a car accident in Arizona. Even though the young man was comatose and had a severe infection, the hospital repatriated him to Mexico because he had not been a lawful permanent resident for long enough to qualify for Medicaid funding in Arizona. ${ }^{24}$

The vast majority of these forced or coerced repatriations take place quietly and privately without intervention from immigration authorities or the courts. In the only known case that involved a legal challenge to the practice, the hospital circumvented federal supremacy over immigration matters and obtained an order authorizing forced repatriation from a state court. ${ }^{25}$ During the pendency of an appeal by the guardian, and after the court-ordered briefing, the hospital forced the brain-damaged migrant worker onto a private plane and flew him to a hospital in Guatemala that could not treat brain injuries. ${ }^{26}$ Because the hospital in Guatemala was unable to provide him the care he needed, he was quickly discharged to the care of his elderly mother. $\mathrm{He}$ now lives with her in a one-room hilltop house in a remote village, where he is bedridden and suffers from frequent seizures. ${ }^{27}$

Throughout numerous similar stories, common themes arise. Immigrants who survive, or the family members of those who do not, describe their loved ones being ushered out of hospitals through back

23. The hospital in Nevada transported a patient, who had been hit by a car and had severe spinal injuries, to Guatemala against his family's wishes and without arranging for transfer to another medical facility. An air ambulance took him to the Guatemala City airport, where the patient's family met him on the tarmac and then transported him via taxicab to a local hospital. He died shortly after his return. Case of Alberto D., documented by the Ctr. for Soc. Justice (on file with author).

24. Due to differences in state funding schemes, the young man's parents were able to bring their son back for treatment in California. He returned from Mexico comatose and with potentially fatal septic shock, but within eighteen days after being admitted to the California hospital, he emerged from his coma, was transferred to a rehabilitation center and ultimately discharged to his lawful permanent resident family in the U.S. Nessel, supra note 10 , at $1752-53$.

25. See Nessel, supra note 10, at 1750-51; Lori A Nessel, Lori A. Nessel on the Legality and Ethics of Medical Repatriation, LEXISNEXIS EMERGING ISSUES L COMMUNTTY (Oct. 7, 2009, 10:28 AM), $\mathrm{http} / / \mathrm{www}$.lexisnexis.com/community/emergingissues/blogs/emergingissuescommentary/archive/200 9/10/07/lori-a.-nessel-on-the-legality-andethics-of-medical-repatriation.aspx.

26. See Sontag, supra note 11. See also Montejo v. Martin Mem'l Med. Ctr., 874 So. 2d 654 (Fla. Dist. Ct. App. 2004).

27. See Sontag, supra note 11. 
doors meant for garbage, under the cover of darkness. In addition to the accounts of hospitals deporting seriously ill or catastrophically injured immigrants, hospitals are also increasingly refusing to treat immigrants because of their immigration status and ineligibility for health care benefits. For example, a hospital in Maryland went to court to have a guardian appointed in order to override a family's wishes and to disconnect the life-sustaining feeding tube of a Rwandan woman. ${ }^{28}$ Although the hospital denied that the woman's immigration status played a role in the decision to disconnect the feeding tube, the guardian remarked, in explaining to the six adult children why their wishes were being overridden, that "feeding tubes are not a part of [Rwandan] culture." 29

The United States is not alone in treating migrants and their families as expendable and in failing to provide basic life-sustaining treatments to migrants. For example, immigration authorities in the United Kingdom came under public scrutiny after deporting a terminally ill woman who had resided in Wales for four years to Ghana, notwithstanding that life-sustaining treatment would not be available for her there..$^{30}$ She died two months later. ${ }^{31}$ Although the act was described in the media as "atrocious barbarism," the immigration authorities maintained that the United Kingdom could not offer health care to people with no legal rights to remain in Britain solely because similar treatment would not be available in their own country. ${ }^{32}$ Human rights groups and the media have also exposed the United Kingdom's failure to provide required vaccinations to immigrants, including children, prior to deportation to regions that require such vaccinations for entry. ${ }^{33}$

28. Deborah Sontag, Immigrant's Health Crisis Leaves Her Family on Sideline, N.Y. TIMES, Mar. 4, 2011, at A13.

29. Id.

30. See Woman Deported to Ghana Despite Cancer Dies, TELEGRAPH (Mar. 20, 2008, 8:25 AM), http://www.telegraph.co.uk/news/uknews/1582270/Woman-deported-to-Ghanadespite-cancer-dies.html. As the Archbishop of Wales remarked, a "civilized, wealthy society" had turned "a sick woman out of her bed and put her on a plane ... I believe her death is on the conscience of this nation because we deported her when it was against every humanitarian instinct to do so." Id.

31. Id.

32. Id.; see also Migrant Health: What Are Doctors' Leaders Doing?, 371 LANCET 178 (2008), available at http://www.thelancet.com/journals/lancet/article/PIIS0140. 6736(08)60111-7/fulltext (noting that other immigrants have also been denied medical treatment and deported and stating that " $[t] 0$ stop treating patients in the knowledge that they are being sent home to die is an unacceptable breach of the duties of any health professional").

33. See The UK's Continued Shameful Neglect of Migrants' Health, 376 LANCET 1438 (2010), available at http://www.thelancet.com/journals/lancet/article/PIIS0140. 
Notwithstanding Canada's reputation for having a humanitarianbased immigration regime, immigrants in Canada can be placed in deportation proceedings if their health problems could "cause excessive demand on health or social services." 34 Applications for permanent residency are also often rejected for this reason. ${ }^{35}$ For example, the federal immigration agency rejected a permanent residency application for a French family that had lived in Montreal for five years, alleging that their eight-year-old daughter with cerebral palsy would be an "excessive burden" on the state's social services. ${ }^{36}$ Thankfully, after media attention and public and political pressure, the federal and provincial immigration agencies reached an agreement to allow the family to remain in Canada as permanent residents. ${ }^{37}$

In another Canadian case arising in the province of New Brunswick, a Korean family sought permanent residency after living and running a business in Canada for over seven years. The family was placed in deportation proceedings after the immigration service found that the youngest son's epilepsy and autism might pose a burden on the state, despite that the boy was home schooled and did not require expensive medication, and that his hospital care costs over the past four years

6736(10)61975-7/fulltext (noting "[a]ny country that purports to uphold human rights and look after its vulnerable people has a duty to ensure that required prevention and treatment is given to all").

34. Immigration and Refugee Protection Act, S.C. 2003, c. 27 sec. 38(1)(c) (Can.). Under Canadian immigration law, "excessive demand" is defined as a demand on health or social services for which the anticipated costs, "would likely exceed average Canadian per capita health services and social services costs" over a period of five (or in certain circumstances ten) consecutive years immediately following the most recent medical examination required under the regulations; or "a demand on health services or social services that would add to existing waiting lists and would increase the rate of mortality and morbidity in Canada as a result of an inability to provide timely services to Canadian citizens or permanent residents." Immigration and Refugee Protection Regulations, SOR/2002-227 (Can.).

35. OfFice OF the Auditor General of CAN., 2011 FALl REPORT, at 2.74 (2011), available at http://www.oag-bvg.gc.ca/internet/English/parl_oag_201111_02_e_35934.html ("In 2010, [Citizenship and Immigration Canada] conducted more than 545,000 medical examinations resulting in some 1,200 applicants [0.22 percent] being found inadmissible for health reasons. Of those, less than 2 percent were considered a danger to public health or safety [the others were denied due to excessive demand on health or social services].").

36. See Katherine Wilton, Desperate Barlagne Family Seeks Politicians' Help to Stay, MONTREAL GAZETTE, Apr. 14, 2011. The family is seeking a stay to remain in Canada on humanitarian grounds. Id.

37. See Family With Disabled Child Can Stay in Canada, CBCnews (Apr. 20, 2011, 8:41 AM), http://www.cbc.ca/news/canada/montreal/story/2011/04/20/barlagne-familyresidency.html. 
were estimated at only $\$ 1,000 .^{38}$ The federal immigration service ultimately rescinded its deportation order after a massive public outcry against the decision and a commitment from the province of New Brunswick to cover all health costs for the boy. ${ }^{39}$

Finally, in a recent Canadian Federal Court of Appeals decision, a unanimous panel upheld the denial of life-sustaining health care to an immigrant woman who had lived and worked in Canada since 1999, but, due to her illness, could no longer work or pay for her medical care on her own. ${ }^{40}$ In rejecting the claim that excluding the seriously ill longterm resident from health care was arbitrary and therefore inconsistent with principles of fundamental justice, the court did not mince words in highlighting the underlying policy and practical issues at stake. As the judge explained:

I see nothing arbitrary in denying financial coverage for health care to persons who have chosen to enter and remain in Canada illegally. To grant such coverage to those persons would make Canada a health-care safehaven for all who require health care and health care services. There is nothing fundamentally unjust in refusing to create such a situation. ${ }^{41}$

This global unwillingness to provide necessary medical care to immigrants is often justified based on the cost that would be associated with treatment. While this theme seems to resonate with the public, the exorbitant cost associated with detention of migrants does not appear to be a subject of concern, ${ }^{42}$ even though studies have shown that alternatives to detention would save taxpayer dollars and be more effective. ${ }^{43}$

38. See Michael McDonald, Sung-Joo Maeng Family Deportation Order Rescinded: Report, CAN. PrEss, June 9, 2011, available at http://www.huffingtonpost.ca/2011/06/09/ sung-joo-maeng-family-deportation_n_874421.html.

39. Id.

40. Toussaint v. Attorney General of Canada, [2011] F.C. 213 (Can. Fed. Ct. App.).

41. Id. at ๆ 83.

42. The cost of immigrant detention in 2010 was estimated to cost taxpayers over $\$ 1.7$ billion. NAT'L IMMigr. F., THE MATH OF IMMIGRATION DETENTION: RUNAWAY COSTS FOR IMMIGRATION DETENTION DO NOT ADD UP TO SENSIBLE POLICIES 3 (2011).

43. See, e.g., Press Release, U.S. Dep't of Homeland Sec., ICE Detention Reform: Principles and Next Steps (Oct. 6, 2009), http://www.dhs.gov/xlibrary/assets/ press_ice_detention_reform_fact_sheet.pdf (setting forth new initiatives in detention reform and concluding that "[alternatives to detention] cost] substantially less per day than detention: the most expensive form of [alternatives to detention] costs only $\$ 14$ per day compared to the cost of detention, which varies per facility but can exceed $\$ 100$ per day"); DET. WATCH NETWORK, POLICY BRIEF: COMMUNITY-BASED ALTERNATIVES TO IMMIGRATION 
What appears to be unique about the extrajudicial medical repatriations occurring in the United States is that they are being carried out directly by hospitals and private transport companies, rather than by immigration authorities. As two of the Canadian examples above illustrate, the public was able to express outrage when the federal deportation orders became public, and the families were able to pursue compassionate immigration relief or a rescission of the deportation order. In contrast, when private actors carry out medical repatriations, there is no transparency or governmental oversight or avenue for appeal. As explored below, the case of medical repatriations serve as a stark example of the dangers in the increased privatization of immigration enforcement.

\section{PRIVAtization of ImMigration ENForCEMENT FUnCTIONS}

In the United States, pursuant to the "plenary power doctrine," the power to regulate immigration is entrusted to the federal government, rather than to the individual states. ${ }^{44}$ Moreover, within the federal government, this power is exclusively vested with the political branches of the government-the executive and legislative-and the judicial branch possesses a very limited power of review. ${ }^{45}$ The Supremacy

DETENTION (2010), http://www.detentionwatchnetwork.org/sites/detentionwatchnetwork.org/ files/DWN\%20ATD\%20Report\%20FINAL_08-25-2010.pdf ("[C]ommunity-based alternatives to detention . . . are cheaper, more effective, and more humane than the current U.S. immigration detention system."); see also Press Release, ACLU, Securely Insecure: The Real Costs, Consequences \& Human Face of Immigration Detention, http://www.acluga.org/FactSheetSecurelyInsecure.pdf (noting that according to a 2009 study, the daily cost of detention has risen to nearly $\$ 141.00$ per day).

44. See, e.g., DeCanas v. Bica, 424 U.S. 351, 354 (1976); Henderson v. Mayor of New York, 92 U.S. 259, 270 (1875).

45. The Supreme Court has "Tong recognized the power to expel or exclude aliens as a fundamental sovereign attribute exercised by the Government's political departments largely immune from judicial control." Shaughnessy v. United States ex rel. Mezei, 345 U.S. 206, 210 (1953). According to the Court, "[C]ongress may, if it sees fit . . a authorize the courts to investigate and ascertain the facts on which the right [of an alien] to land depends. But . . . the final determination of those facts may be entrusted by [C]ongress to executive officers; and in such a case, as in all others, in which a statute gives a discretionary power to an officer, to be exercised by him upon his own opinion of certain facts, he is made the sole and exclusive judge of the existence of those facts, and no other tribunal, unless expressly authorized by law to do so, is at liberty to re-examine or controvert the sufficiency of the evidence on which he acted." Ekiu v. United States, 142 U.S. 651, 660 (1892); accord Ping v. United States, 130 U.S. 581, 603-04, 609 (1889) ("That the government of the United States, through the action of the legislative department, can exclude aliens from its territory is a proposition which we do not think open to controversy. Jurisdiction over its own territory to that extent is an incident of every independent nation. It is a part of its independence. If it could not exclude aliens it would 
Clause of the U.S. Constitution provides that federal laws are supreme to state laws. Accordingly, "[i]n every such case [where state law conflicts with federal law], the act of Congress, or the treaty, is supreme; and the law of the state, though enacted in the exercise of powers not controverted, must yield to it." 46

Notwithstanding the supremacy of the federal government's power to regulate immigration, individual states increasingly have become involved in enforcing immigration laws. In some instances, this has been due to congressional legislation that opened the door to cooperation between states and the federal immigration authorities in working to enforce immigration laws. ${ }^{47}$ However, independent of any federal government regulation, and at times in conflict with existing laws and regulations, individual states and municipalities are enacting laws and

be to that extent subject to the control of another power.. . Whether a proper consideration by our government of its previous laws, or a proper respect for the nation whose subjects are affected by its action, ought to have qualified its inhibition and made it applicable only to persons departing from the country after the passage of the act, are not questions for judicial determination. If there be any just ground of complaint on the part of China, it must be made to the political department of our government, which is alone competent to act upon the subject."); Ting v. United States, 149 U.S. 698, 730 (1893) ("The order of deportation is not a punishment for crime. It is not a banishment, in the sense in which that word is often applied to the expulsion of a citizen from his country by way of punishment. It is but a method of enforcing the return to his own country of an alien who has not complied with the conditions upon the performance of which the government of the nation, acting within its constitutional authority and through the proper departments, has determined that his continuing to reside here shall depend. He has not, therefore, been deprived of life, liberty or property without due process of law; and the provisions of the [C]onstitution, securing the right of trial by jury, and prohibiting unreasonable searches and seizures and cruel and unusual punishments, have no application.").

46. Gibbons v. Ogden, 22 U.S. 1, 211 (1824).

47. As reported by the UN Special Rapporteur on Migrant Rights, while migration is a federal matter, Immigration and Customs Enforcement (ICE) is actively seeking the assistance of state and local law enforcement in carrying out its enforcement of immigration law. Pursuant to federal law, ICE is permitted to enter into agreements with state and local law enforcement agencies through voluntary programs that allow designated officers to carry out immigration law enforcement functions. These state and local law enforcement agencies enter into a memorandum of understanding (MOU) or a memorandum of agreement (MOA) that outlines the scope and limitation of their authority. According to ICE, over 21,485 law enforcement officers nationwide are participating in this program, and more than forty municipal, county, and state agencies have applied. In 2006, this program resulted in 6,043 arrests. See Special Rapporteur on the Human Rights of Migrants, Promotion and Protection of all Human Rights, Civil, Political, Economic, Social and Cultural Rights, Including the Right to Development, I 57, U.N. Doc. A/HRC/7/12/Add.2 (Mar. 5, 2008) [hereinafter Promotion and Protection Report]. 
ordinances to limit the rights of immigrants and curtail immigration across their borders. ${ }^{48}$

The federal government has an important interest in maintaining federal control over immigration regulation. This interest is evidenced by the expense and time the United States is allocating in litigation against Arizona's anti-immigration laws. ${ }^{49}$ As illustrated by the proliferation of anti-immigration laws and ordinances being proposed in particular states, if immigration regulation is not an exclusive function of the federal government, there will be no uniformity in immigration laws or policies and discrimination and civil rights violations against immigrants will be rampant. 50

48. See infra notes $49-50$ and accompanying text. Examples of municipal ordinances attempting to curtail immigration also abound, including the cities of Hazleton, Pennsylvania (rental tenants must have proof of legal residence and occupancy licenses in order to rent; landlords who rent to undocumented workers will be fined; business licenses are denied to those who employ undocumented workers), Valley Park, Montana (employers who fail to use E-Verify [a system that allows employers to determine the eligibility of their workers to work in the United States] will be fined), Farmers Branch, Texas (ordinance fines landlords who rent to undocumented workers), and Fremont, Nebraska (like the ordinance in Hazelton, PA, this ordinance allows for fines for both landlords and businesses that either employ or rent to undocumented workers). $S$. POVERTY LAW CTR., WHEN MR. KOBACH COMES TO TOWN: NATTVIST LAWS \& THE COMMUNITIES THEY DAMAGE 21-24 (2011). Other municipalities, such as Riverside, New Jersey, abandoned their anti-immigration ordinances in the face of exceedingly high costs. Diane Wetherbee \& Paige Mims, InT'L Mun. LAWYers Ass'N, Immigration: Local REFORM, REGULATION, AND RESPONSE 7-8 (2009), http:/www.txgovernmentlawyer.org/ Immigration\%20Paper\%20for\%20IMLA.pdf.

49. See United States v. Arizona, 703 F. Supp. 2d 980, 987, 996 (D. Ariz. 2010) ("Congress has created and refined a complex and detailed statutory framework regulating immigration ... [SB 1070] will divert resources from the federal government's other responsibilities and priorities."), affd in part, United States v. Arizona, 641 F.3d 339 (9th Cir. 2011). It is estimated that as of February 11, 2011, Arizona had already spent more than $\$ 1.5$ million defending SB 1070. Ginger Rough, \$1.5 Million Spend Defending SB 1070, ARIZ. REPUBLIC (Feb. 25, 2011, 12:00 AM), http://www.azcentral.com/12news/news/articles/2011/02/25/ 20110225arizona-immigration-bill-lawsuit-cost-millions.html. The United States Supreme Court will hear oral arguments in Arizona v. United States on April 25, 2012, and the Court's ruling on a state's ability to regulate immigration will likely determine the viability of immigration laws in Georgia, Alabama, South Carolina, Indiana and Utah. See Arizona Immigration Law's Supreme Court Oral Argument Set for April, HuFFINGTON PosT (Feb. 5, 2012, 12:28 PM), http:/www.huffingtonpost.com/2012/02/03/arizona-immigration-lawn_1253502.html; Georgia: Court Delays Ruling on Immigration Laws, N.Y. TIMES (March 2, 2012), http://www.nytimes.com/2012/03/02/us/georgia-court-delays-ruling-on-immigrationlaws.html (reporting that the U.S. Supreme Court's ruling will likely affect the legality of similar laws in Georgia and Alabama).

50. Arizona's Support Our Law Enforcement and Safe Neighborhoods Act [SB 1070] makes "the failure to carry immigration documents a crime and give[s] the police broad power to detain anyone suspected of being in the country illegally." Randal C. Archibold, Arizona Enacts Stringent Law on Immigration, N.Y. TIMES, Apr. 23, 2010, at A1. The 
In addition to the shift in the power to regulate immigration from the federal to state and local governments, immigration enforcement has been delegated to private actors in many ways over recent years. ${ }^{51}$ For example, the Department of Homeland Security (DHS) contracted with Blackwater USA, which became notorious for its military actions and killing of civilians in Iraq, ${ }^{52}$ to guard the U.S.-Mexico border. ${ }^{53}$

United States Court of Appeals for the Ninth Circuit stated: "[SB 1070] subverts Congress' intent that systematic state immigration enforcement will occur under the direction and close supervision of the [executive branch] . . the mandatory nature of Section 2(B)'s immigration status checks is inconsistent with the discretion Congress vested in the [executive branch] to supervise and direct State officers in their immigration work according to federally-determined priorities." United States v. Arizona, 641 F.3d at 352. In light of Arizona's immigration regulation, Georgia, Utah, Indiana and Alabama have passed similar legislation. For example, Georgia's law institutes new employment eligibility verification requirements and permits police investigation of undocumented immigration status in certain circumstances. Illegal Immigration Reform and Enforcement Act, H.B. 87 (Ga. 2011). Alabama's law "requires local law enforcement, in some instances, to verify the immigration status of those stopped for traffic violations, public schools to determine the immigration status of students, employers to use E-Verify and makes it a crime to knowingly rent to, transport or harbor undocumented immigrants." Seth Hoy, Alabama Governor Signs Costly Immigration Bill, ACLU to File Suit, IMMIGRATION IMPACT (June 10, 2011), http://immigrationimpact.com/2011/06/10/ alabama-governor-signs-costly-immigration-bill-aclu-to-file-suit/.

51. See Huyen Pham, The Private Enforcement of Immigration Laws, 96 GEo. L. J. 777 (2008) (discussing the move toward private enforcement of immigration laws in employment, housing and transportation and noting a new interest in privatization in areas including education, health care and charity services). As Professor Pham notes, hospitals have spoken out against legislative attempts to require hospitals to report the immigration status of patients.

One noteworthy defeat in the U.S. Congress was of House Resolution 3722 , introduced by Rep. Dana Rohrabacher in 2004. This bill would have required hospitals seeking federal reimbursement for care provided to undocumented patients to ask whether patients are U.S. citizens before providing care. Non-citizens unable to provide a Green Card or other proof of legal status would have to be fingerprinted or photographed by the hospital, and this information would be made available to ICE officials, who could initiate deportations. Undocumented patients would also be required to disclose their employers, who then would be required to pay for their employees' care. The bill also prohibited hospitals from providing most types of medical treatment, unless the care was needed to 'protect the health and safety' of U.S. citizens. The American Hospital Association and other medical industry groups lobbied fiercely against this bill, with Id. at 798-99. the result that the bill was soundly defeated, 331 to 88 .

Phan notes that "[w]hen hospitals do deny care based on immigration status, they are doing so voluntarily for financial reasons, rather than being compelled by private enforcement laws to do so." Id. at 799.

52. Although investigators concluded that security guards employed by Blackwater, USA had indiscriminately fired on unarmed civilians in an unjustified attack near a crowded traffic circle on September 16, 2007, resulting in the death of seventeen Iraqis and 
Perhaps the best example of the privatization of immigration enforcement is the dramatic rise in detention facilities that are run by private corporations. ${ }^{54}$

The question then is whether the shift in immigration enforcement from the federal government to the state, locality, workplace, or even hospital room simultaneously is insulating the state and undermining transparency while compromising the guarantee of basic human rights for migrant workers. Privatization of immigration regulation has been widely criticized because it undermines domestic constitutional protections. ${ }^{55}$ However, when immigration enforcement is explicitly

approximately twenty wounded, a federal court judge ultimately dismissed the case against the former Blackwater guards because of the government's mishandling of the case. See Charlie Savage, Judge Drops Charges from Blackwater Deaths in Iraq, N.Y. TIMES (Dec. 31, 2009), http://www.nytimes.com/2010/01/01/us/01blackwater.html. The wrongful death litigation related to the Blackwater guards' actions was settled for an undisclosed amount in January 2012. See Blackwater Settles Iraq Killings Legal Case, ALJAZEERA (Jan. 10, 2012, 4:34 AM), http://www.aljazeera.com/news/americas/2012/01/2012176192887652.html.

53. See Robert Koulish, Blackwater and the Privatization of Immigration Control, 20 ST. THOMAS L. REV. 462, 462-63 (2008) (describing the scale of Blackwater's proposed operations on the U.S.-Mexico border, including an arsenal of weapons and a massive training complex where the company plans to make a large profit by charging the U.S. government to prevent illegal border-crossings); see also George A. Martinez, Bobbitt, the Rise of the Market State, and Race, 18 AM. U. J. GENDER SOC. POL'Y \& L. 587 (2010).

54. See Koulish, supra note 53, at 477 (using Blackwater's role in enforcing the U.S. Mexico border as an example to argue that immigration law is providing an infrastructure for the privatization of an undemocratic domestic war on terror). As Koulish notes, while the privatization of immigration detention is not new, "[w] hat is new is the expansiveness of privatization after 9/11 and its use in establishing a social control apparatus ostensibly for non-citizens but which is applicable to citizens ... In the aftermath of 9/11, the private prison industry has once again experienced a boom as national security has been involved to sweep up and jail an unprecedented number of immigrants. Immigrants are currently the fastest growing segment of the prison population in the U.S. today." Id. (citations omitted). Notably, in the months following February 2006, when President Bush proposed increasing spending on immigrant detention, stock for the Correctional Corporation of America (one of the largest private companies involved in immigrant detention) rose by 27 percent. Id. (internal citations omitted); see also Spencer Bruck, The Impact of Constitutional Liability and Private Contracting on Health Care Services for Immigrants in Civil Detention, 25 GEo. IMMIGR. L. J. 487, 491-92 (2011) ("In discussing the importance of immigration policy's dependence on detention and its relations to private prison operation, GEO, the second largest private prison firm, stated in its public financial disclosures: ' $[A]$ ny . . . loosening of immigration laws could affect the number of persons arrested, convicted, sentenced and incarcerated, thereby potentially reducing demand for correctional facilities to house them.' The federal government's devotion to civil detention of immigrants has created a massive new market and provides an opportunity to impose public norms on private corporations.") (citing Alexander Volokh, Privatization and the Law and Economics of Political Advocacy, 60 STAN. L. REv. 1197, 1225 (2008)).

55. See Koulish, supra note 53, at 471-73 (noting that the privatization of immigration control removes many forms of oversight and redress). For example, many constitutional norms, such as the right to due process, do not apply to private contractors. Private 
delegated to a private company, the government can still be held responsible for human rights abuses. ${ }^{56}$

Unlike delegation of authority to private companies in other settings, such as detention, DHS has not explicitly delegated immigration enforcement to hospitals or to private transport companies. Rather, hospitals have deputized themselves to engage in deportations as a method of reducing long-term-care costs. Hospitals then delegate their obligation to provide medical treatment to private transport companies that engage in de facto deportations. ${ }^{57}$ Notwithstanding the lack of explicit delegation of a traditional governmental function, the government may-and must-be held accountable for its failure to exercise due diligence to protect against known human rights violations by private actors.

In a typical medical repatriation scenario, the hospital calls the Immigration and Customs Enforcement (ICE) division of DHS and requests that ICE place the undocumented immigrant in removal proceedings. ICE usually fails to respond to such calls from hospitals. 58 If ICE were to respond and place the person in detention and removal proceedings, it would have to assume the costs of health care, as well as the liability for failure to provide proper health care. ${ }^{59}$ Deporting

contractors are also not considered "state actors" for purposes of 42 U.S.C. $\S 1983$ "under color of law" liability. As Koulish points out, by using private contractors, the executive branch can further limit congressional oversight on immigration policy. For instance, when the executive hires contractors for immigration enforcement or detention, Congress' access to these contracts is limited. Further, private companies are not required to divulge information requested by Congress or the public; they are less rule-bound than public entities and make decisions behind closed doors. Finally, they are not subject to the notice and comment provisions of the Administrative Procedures Act (APA). See also Laura A. Dickinson, Public Law Values in a Privatized World, 31 YALE J. INT'L L. 383, 384 (2006).

56. For example, in Jama v. United States (Jama I), 22 F. Supp. 2d 353, 358, 365-66 (D. N.J. 1998), the court held that Esmor, a private company that had contracted with the I.N.S. to run a detention facility for asylum seekers, was a state actor because it was performing a governmental function. Because the private actor was effectively a state actor, its employees (including prison guards) could be held liable for violation of the law of nations under the Alien Tort Claims Act. Id. at 363-66. The court further clarified that private contractors can violate the law of nations if the conduct is severe enough and there is sufficient state involvement. Id. at 363 .

57. See Lori A. Nessel, The Practice of Medical Repatriation: The Privatization of Immigration Enforcement and Denial of Human Rights, 55 WAYNE L. REV. 1725, 1728-29 (2009).

58. As reported by Deborah Sontag in her series on medical repatriations in the New York Times, a spokeswoman for ICE explained that "[ICE] does not get involved in repatriations undertaken by hospitals." Sontag, supra note 17.

59. ICE's ability to provide appropriate medical care to immigrants that are already in its custody has been the subject of widespread criticism and litigation. See Nicole Therrien \& Angela Mattie, Improving Medical Care for Detained Immigrants: A Call for a Legislative Action, 22 J. HeALTH CARE FOR POOR \& UNDERSERVED 437, 438 (2011) (noting that, although 
seriously ill immigrants that may die after deportation would also garner negative publicity for ICE. As a result, seriously ill immigrants without criminal convictions or other negative histories are not a high priority for ICE for removal from the United States. ${ }^{60}$

For the aforementioned reasons, there is no incentive for ICE to become involved in the removal of seriously ill immigrants. ${ }^{61}$ By taking

there is a substantial range in the availability of medical services at detention facilities in the United States, the consistent absence of oversight or a system to monitor adherence to medical protocols often prevents detainees from receiving needed health care); US: Immigration Detention Practices Endanger Health, Life, DET. WATCH NETWORK, (Dec. 7, 2007), http://www.detentionwatchnetwork.org/node/495 (outlining the failure of facilities that detain immigrants with HIV to consistently deliver antiretroviral medications, conduct necessary laboratory tests, ensure continuity of care or confidentiality or protection from discrimination, and arguing that existing guidelines fail to meet national and international standards of appropriate care); CBS News: Detention in America, (CBS television broadcast Feb. 11, 2009), available at http://www.cbsnews.com/stories/2008/05/09/60minutes/ main4083279.shtml (concluding that the number of immigrant deaths in detention reveals a pattern of "poor medical judgments, faulty administrative practices, sloppy paperwork, lost medical records and very dangerous staffing levels"). ICE's treatment of detained immigrants in need of medical care has also resulted in litigation. See Press Release, ACLU, ACLU Sues U.S. Immigration Officials and For-Profit Corrections Corporation Over Grossly Deficient Healthcare, (June 13, 2007), available at http://www.aclu.org/immigrantsrights/aclu-sues-us-immigration-officials-and-profit-corrections-corporation-over-grossly (announcing ACLU litigation against a San Diego private detention facility, alleging that chronically severe overcrowding places detainees' health and safety at risk, is unconstitutional, and has led to violence).

60. An ICE policy guidance memorandum states that it is the "[R]esponsibility of [Office of Detention and Removal Operations] staff to use judicious discretion in identifying and responding to meritorious health related cases in which detention may not be in the best interest of U.S. Immigration and Customs Enforcement (ICE) . . Field officers are not only authorized ... to exercise discretion ... but are expected to do so ...." The memorandum articulates reasons for discretion, including (1) compassion and humanitarian concern; (2) reducing catastrophic health care costs; and (3) maximizing impact on enforcement and removal by not detaining aliens who are unable to complete the removal process because of their severe illness. Memorandum from John P. Torres, Dir., U.S. Immigration \& Customs Enforcement, to Assistant Directors et al. on Discretion in Cases of Extreme or Severe Medical Concerns (Dec. 11, 2006), http://www.ice.gov/doclib/foia/dro_policy_memos/ discretionincasesofextremeorseveremedicalconcerndec112006.pdf. Moreover, a June 2011 ICE memorandum on prosecutorial discretion identifies "P]ositive factors [that] should prompt particular care and consideration ..." including, but not limited to (1) individuals who suffer from a serious mental or physical disability; and (2) individuals with serious health concerns. Memorandum from John Morton, Dir., U.S. Immigration \& Customs Enforcement, to all Field Office Directors, Special Agents in Charge, and Chief Counsel, U.S. Immigration \& Customs Enforcement on Exercising Prosecutorial Discretion Consistent with the Civil Immigration Enforcement Priorities of the Agency for the Apprehension, Detention, and Removal of Aliens (June 17, 2011), http://www.ice.gov/doclib/securecommunities/pdf/prosecutorial-discretion-memo.pdf.

61. ICE's treatment of mentally ill detainees has been widely criticized. See TEX.

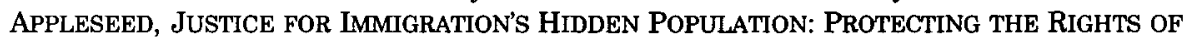


matters, including deportation, into their own hands, hospitals are circumventing federal supremacy over immigration, while, at the same time, potentially insulating themselves and the state from liability under a human rights regime that focuses on state action.

Undocumented immigrants with serious health needs thus find themselves in a situation in which no entity has any interest in assuming responsibility for them. Hospitals and rehabilitation centers know that they will not be reimbursed for costly, needed treatment. The federal agency charged with regulating immigration has nothing to gain by immersing itself in this controversial arena. U.S. consulates from the immigrant's home country may also be reluctant to assume responsibility if the national needs medical care that cannot be accessed in the home country.

In addition to the lack of incentive for hospitals to provide ongoing treatment or for appropriate governmental entities to become involved, the reality is that there are no viable sanctions for hospitals that resort to private deportations. ${ }^{62}$ In the only known litigation brought against a hospital to challenge the practice of medical repatriation, a jury found the hospital not liable for allegations of false imprisonment by a severely brain-damaged migrant laborer that claimed the hospital forced him, against his will, on a private plane and flew him to a hospital in Guatemala that could not treat him. ${ }^{63}$

All too often, the combination of desperate immigrants and a lack of governmental oversight or accountability results in exploitation by unscrupulous private actors, either operating independently or in a contractual capacity for government entities. Examples of this

Persons with Mental Disabilities in the Immigration Court and Detention System (2010), available at http://graphics8.nytimes.com/packages/pdf/national/30immig_report.pdf. Even in referring to the immigration detention system that ICE administers, Tom Barry of the Center for International Policy noted that "[i]n this bizarre labyrinth of contracts and sub contracts, what's lost is accountability, transparency, responsibility. It is very difficult to know who is responsible and oversight gets lost." Id. at 10; accord id. at 7 (making recommendations for improving detention and apprehension of immigrants with mental health disorders).

62. See Seton Hall Univ. School of Law Center for Social Justice \& the Health Justice Project of the N.Y. Lawyers for the Public Interest, Discharge or Deportation? Hospitals Enforcing Immigration Laws, 2012 (forthcoming) (on file with author).

63. Montejo v. Martin Mem'l Med. Ctr., 874 So. 2d 654, 658 (Fla. Dist. Ct. App. 2004). The state appellate court ruled that the lower state court that ordered the immigrant's repatriation from the hospital lacked subject matter jurisdiction because it was preempted by federal jurisdiction over immigration regulation. Id.; see also Nessel, supra note 25, at 3 (explaining that notwithstanding the court's ruling that the hospital's action was unlawful, the jury in a subsequent damages case nevertheless found that the hospital's action was not "unreasonable and unwarranted under the circumstances" as required under Florida law for the tort of false imprisonment). 
exploitation include the networks of individuals engaged in human trafficking and labor exploitation. ${ }^{64}$ It comes as no surprise then that the void created by the lack of funding for services or accountability for unlawful private medical repatriations has led to a profit-making business in private repatriations. ${ }^{65}$

Given the lack of accountability under domestic law, an approach that focuses instead on the basic dignities that are guaranteed to all human beings under international human rights law offers an alternative perspective, with the potential to broaden the debate beyond issues of immigration status or costs. However, as explored below, while such a human rights-based approach helps to redefine the problem, the doctrine's deference to sovereignty and its focus on the role of the state, rather than the individual, may pose significant limitations to protection. Moreover, the limitations of both domestic law and the international human rights regime suggest that truly addressing the moral dilemma posed by private deportations of injured or ill migrants would require a deeper examination of the value accorded to migrant labor and the factors that influence migration, both in the home country and the receiving country.

\section{THE VALUE AND LIMITATIONS OF APPLYING AN INTERNATIONAL HUMAN RIGHTS-BASED FRAMEWORK TO THE PRACTICE OF FORCED OR COERCED MEDICAL REPATRIATIONS}

Hospitals that repatriate seriously ill or injured migrants justify their actions on the exorbitant costs associated with ongoing treatment and the lack of federal reimbursement for services rendered to immigrants that do not qualify for aid. ${ }^{66}$ To the extent that the public is

64. See Jennifer Chacon, Misery and Myopia: Understanding the Failures of U.S. Efforts to Stop Human Trafficking, 74 FORDHAM L. REV. 2977, 2979 (2006) (arguing that current labor and immigration law enforcement actually creates incentives for trafficking and other forms of migrant exploitation in the United States). In 2010, the Justice Department indicted a Los Angeles company, Global Horizons Manpower, on forced labor charges for abusing the federal guest worker program. According to the New York Times: "The workers, poor men from the Thai countryside, took on crushing debt to pay exorbitant recruiting fees, about $\$ 9,500$ to $\$ 21,000$. After they arrived in America, according to the indictment, their passports were taken and they were set up in shoddy housing and told that if they complained or fled they would be fired, arrested or deported." Editorial, Forced Labor, N.Y. TTMES, Sept. 7, 2010, http://www.nytimes.com/2010/09/08/ opinion/08wed2.html?ref=humantrafficking.

65. The best-known company is MexCare, a private corporation that advertises itself as "an alternative choice for the acute care of the unfunded Latin American national." Welcome to MexCare, MEXCARE, http://www.mexcare.com/ (last visited Jan. 25, 2012).

66. See, e.g. Deborah Sontag, Immigrants Facing Deportation by U.S. Hospitals, N.Y. TIMES (Aug. 3, 2008), http://www.nytimes.com/2008/08/03/us/ 03deport.html?pagewanted=all 
even aware of the situation, the same sentiments about costs and unlawful immigration status tend to be echoed. ${ }^{67}$ At the same time, from a human rights perspective, the immigrant's most basic guaranteed human rights, including the rights to life, due process in expulsion, health, freedom from discrimination, and family integrity, are in jeopardy. This disconnect between the basic human rights that are at stake and immigration and health care regimes that do not provide for legal immigration status or access to health care for migrants that live and work within the nation reflects the gulf that exists between domestic law and human rights norms when migration is at issue. A human rights-based approach to medical repatriation offers a very different prism that steps away from cost or immigration status and instead examines basic dignities and the role of the state.

Under international human rights law, the United States is bound by a number of international treaties, conventions, and norms. The Universal Declaration on Human Rights (UDHR) guarantees a right to life and to health. ${ }^{68}$ The International Covenant on Civil and Political Rights (ICCPR) commits its signatories to respect the civil and political rights of individuals, including the rights to life, freedom from inhuman or degrading treatment or punishment, liberty and security of the person, equality before the law, and freedoms of privacy, religion, opinion, expression, association, and peaceful assembly. ${ }^{69}$ The International Convention to End Racial Discrimination (ICERD) seeks both to end racial discrimination in all its forms and to promote understanding among all races. ${ }^{70}$ Signatories must not discriminate on the basis of race or sponsor or defend racism, and must prohibit race discrimination within their borders. ${ }^{71}$ Finally, the Convention on the Rights of Persons with Disabilities (CRPD) seeks to protect the rights

(reporting that, "[h]ospital administrators view these cases as costly, burdensome patient transfers that force them to shoulder responsibility for the dysfunctional immigration and health-care systems."); see also Agarwal \& Aronchick, supra note 13.

67. For a discussion of reader reactions to the medical deportation of a quadriplegic immigrant who could not afford his medical bills, see Ray Downs, Man Dies From Injuries a Year After Deportation Over Medical Fees, CHRISTIAN POST (Jan. 3, 2012), http://www.christianpost.com/news/man-dies-from-injuries-a-year-after-deportation-overmedical-fees-66273/.

68. Universal Declaration of Human Rights, arts. 3, 25, G.A. Res. 217 (III) A, U.N. Doc. A/RES/217(III) (Dec. 10, 1948) [hereinafter UDHR].

69. International Covenant on Civil and Political Rights, G.A. Res. 2200 (XXI) A, U.N. Doc. ARES/2200(XXI) (Dec. 16, 1966) [hereinafter ICCPR].

70. International Convention on the Elimination of All Forms of Racial Discrimination, G.A. Res. $2106(\mathrm{XX})$ A, U.N. Doc. A/RES/2106(XX), at 5 (Dec. 21, 1965) (hereinafter ICERD].

71. Id. at 2,5 . 
and dignity of all persons with disabilities. ${ }^{72}$ Signatories must promote, protect, and ensure the full enjoyment of human rights and equality under the law of all disabled persons. ${ }^{73}$ The United States, as signatories to the UDHR, the ICCPR, the ICERD, and the newly signed CRPD, is legally bound by the provisions and must endeavor to protect the human rights of all peoples within its borders. ${ }^{74}$

Medical repatriation also implicates multiple human rights protected by the Charter of the Organization of American States and reflected in its Declaration and Convention. ${ }^{75}$ For example, from a human rights perspective, when hospitals in the United States involuntarily send migrant patients to their native countries, the hospitals are effectively engaging in extrajudicial deportations ${ }^{76}$ that are in violation of the right to a fair trial and due process established in the Declaration. ${ }^{77}$ In the United States, only the federal government has

72. Convention on the Rights of Persons with Disabilities, G.A. Res. 61/106, U.N. Doc A/RES/61/106, at 1 (Dec. 13, 2006) [hereinafter U.N. Disabilities Convention].

73. $I d$.

74. The 1969 Vienna Convention on the Law of Treaties states, "[e]very treaty in force is binding upon the parties to it and must be performed by them in good faith." Vienna Convention on the Law of Treaties, art. 26, May 23, 1969, 1155 U.N.T.S. 331 [hereinafter VCLT]. Though the United States has yet to ratify the VCLT, "[m]any commentators believe that the Convention's terms are nonetheless fully binding on the United States as customary international law . . . Curtis A. Bradley \& Jack L. Goldsmith, Treaties, Human Rights, and Conditional Consent, 149 U. PA. L. REV. 399, 424 (2000). The United States has fully ratified the UDHR, ICCPR, and ICERD. While the United States has yet to ratify the U.N. Disabilities Convention, it has signed the treaty. United Nations Enable, Convention and Optional Protocol Signatures and Ratifications (Oct. 10, 2011), http://www.un.org/disabilities/countries.asp?navid=17\&pid=166.

75. The Declaration constitutes a source of international obligations for the United States and other OAS Member States, regardless of whether the States are also parties to the Declaration. See Interpretation of the American Declaration of the Rights and Duties of Man Within the Framework of Article 64 of the American Convention on Human Rights, Advisory Opinion OC-10/89, Inter-Am. Ct. H.R. (ser. A) No. 10, 1 I 35-45 (July 14, 1989); Gonzales v. United States, Petition No. 1490-05, Inter-Am. Comm'n H.R., Report No. 52/07, doc. 19 If 56 (2007) (finding that the American Declaration "constitut[es] a source of legal obligation for OAS member states, including in particular those states that are not parties to the American Convention on Human Rights").

76. Black's Law Dictionary defines "deportation" as " $t]$ he act . . . of removing a person to another country; esp[ecially] the expulsion or transfer of an alien from a country." BLACK'S LAW DICTIONARY 504 (9th ed. 2009).

77. American Declaration of the Rights and Duties of Man, OEA/Ser.L./V.II.23, doc. 21, rev. 6, art. 25 (1948), reprinted in Basic Documents Pertaining to Human Rights in the Inter-American System, OEA/Ser.L.V./II.82, doc. 6 at 17 (1992) ("No person may be deprived of his liberty except in the cases and according to the procedures established by pre-existing law."). 
the power to make deportation decisions. ${ }^{78}$ Immigrants in such removal proceedings are guaranteed basic due process protections, including a hearing before an immigration judge ${ }^{79}$ at which the government carries "the burden of establishing by clear and convincing evidence that ... the alien is deportable,"80 notice of the right to appeal the decision;81 an opportunity to move the immigration judge to reconsider; 82 an opportunity to seek discretionary relief of removal; 83 and an opportunity to obtain habeas review of the decision not to consider waiver of deportation. ${ }^{84}$ As the Inter-American Court on Human Rights has held in interpreting the obligations of all member states in the Organization of American States to uphold the rights guaranteed by the American Declaration on the Rights and Duties of Man, "the due process of law guarantee must be observed in the administrative process and in any other procedure whose decisions may affect the rights of persons." 85

At the most basic level, when hospitals in the United States forcibly repatriate seriously ill or injured immigrants, their actions violate the immigrant patients' rights to liberty and personal security. For example, as noted above, in several cases, immigrants with severe injuries such as head and spinal injuries and paralysis were repatriated by hospitals in several states either without consent-and despite objections from family members and community advocates-or subject to coercion and pressure by hospital staff. ${ }^{86}$ When patients are transferred to inadequate facilities or merely dropped off without

78. 8 U.S.C. $\$ 1229 a(a)(3)(2011)$ ("[A] proceeding under this section shall be the sole and exclusive procedure for determining whether an alien may be . . . removed from the United States.").

79. Id. $\S 1229 \mathrm{a}(\mathrm{a})(1)$.

80. Id. $\S 1229 \mathrm{a}(\mathrm{c})(3)(\mathrm{A})$.

81. Id. $\S 1229 \mathrm{a}(\mathrm{c})(5)$.

82. Id. § $1229 \mathrm{a}(\mathrm{c})(6)$.

83. Id. § $1229 \mathrm{a}(\mathrm{c})(4)(\mathrm{A})$.

84. See Immigration \& Naturalization Serv. v. St. Cyr, 533 U.S. 289, 314-15 (2001). For a discussion of the due process rights of immigrants in removal proceedings, see Kit Johnson, Patients Without Borders: Extralegal Deportation by Hospitals, 78 U. CIN. L. REV. 657, 680 (2009).

85. Sawhoyamaxa Indigenous Community v. Paraguay, Merits, Reparations and Costs, Judgment, Inter-Am. Ct. H.R. (ser. C) No. 146, ๆ 82 (Mar. 29, 2006).

86. For example, in the case of Enrique L., hospital representatives misrepresented a patient's condition in order to obtain consent of family members in Guatemala. Case of Enrique L., supra note 15. In the case of Luis Jimenez, notwithstanding the court's order that the hospital respond to the guardian's opposition to the repatriation order, the hospital acted immediately to repatriate an immigrant with severe brain trauma to a hospital that could not provide appropriate treatment. Sontag, supra note 17. See also Sontag, supra note 11 (recounting the case of Antonio de Jesús Torres, parents of a nineteen-year-old lawful permanent resident in a coma were pressured into consenting to their son's repatriation to Mexico). 
transfer to another facility 87 and subsequently die due to lack of vital care, they are deprived of their right to life.

In addition, Article I of the American Declaration on the Rights and Duties of Man not only protects from death, but it also guarantees the right to live a dignified life. In interpreting this right, the InterAmerican Court has held that it incorporates

not only the right of every human being not to be deprived of his life arbitrarily .. . [but also the right not to be] prevented from having access to the conditions that guarantee a dignified existence. States have the obligation to guarantee the creation of the conditions required in order that violations of this basic right do not occur and, in particular, the duty to prevent its agents from violating it. 88

Utilizing a human rights framework for cases of medical repatriation addresses the way in which this practice violates not just the basic rights of the patient but also the dignity of the family. For example, in cases where patients are unable to consent or make informed decisions about their own health care due to mental or physical incapacitation or age, their family members are often called on to provide such consent. When hospitals in the United States repatriate incapacitated or underage immigrants in contravention of the family's wishes, the practice of medical repatriation violates the patient's and family's right to protection of the family. Any forced or coerced medical repatriations that separate family members also violate the right to family unity. These violations are dramatically illustrated by the closing of the Grady Dialysis Center in Atlanta, Georgia, where long-time residents of the United States were coerced into separating from immediate family in the United States and repatriating to Mexico in hopes of receiving life-sustaining dialysis. ${ }^{89}$

87. See Case of Alberto D., documented by the Ctr. for Soc. Justice (on file with author).

88. Villagrán Morales v. Guatemala ("Street Children" Case), Judgment, Inter. Am. Ct. H.R. (ser. C) No. 63, ๆ 144 (Nov. 19, 1999).

89. See Nessel, supra note 10, at 1741 (recounting the story of a ten year-resident of the United States that agreed to be transferred to Mexico along with her eight-year-old U.S. citizen son, but leaving behind her husband of fifteen years and their fourteen-yearold son, who remained behind to earn money for her dialysis treatments); see also Precautionary Measures Granted by the IACHR during 2010, PM 385-09, http://www.cidh.oas.org/medidas/2010.eng.htm (order on Jan. 29, 2010 granting precautionary measures to thirty-one undocumented immigrants whose dialysis treatments at Grady Memorial Hospital were scheduled to be terminated). 
Migrants are also denied the right to health when hospitals or private transportation companies deny them access to adequate healthcare within the United States and forcibly transport them to facilities in other countries that cannot provide the required care.90 According to the American Medical Association Council on Ethical and Judicial Affairs (CEJA), "millions of legal and illegal noncitizen immigrants are potentially at risk of being unsafely discharged across U.S. borders." 91 Alarmed by the moral and ethical implications of cases involving forced or coerced medical repatriations, the CEJA has taken the position that "[p]hysicians should not discharge a patient to an environment in which the patient's health could reasonably be expected to deteriorate simply because of inadequate resources at the intended destination."92

Forced or coerced medical repatriations also violate a person's right to equality before the law because migrants are being denied their rights to life and preservation of health, based solely on their immigration and economic status. Only seriously ill or injured immigrants without the means to pay their own healthcare costs are victims of these risky transfers to overseas facilities, which jeopardize their health and well-being. Significantly, the Statute of the InterAmerican Commission on Human Rights, Article 20(a), obligates the Commission "to pay particular attention to the observance of the human rights referred to in Article ... II ... of the American Declaration of the Rights and Duties of Man."93 By not treating these patients equally and allowing distinctions among patients because of nationality and economic factors, the United States may be in contravention of Article II. 94

90. Article XI of the American Declaration of the Rights and Duties of Man establishes that "[e]very person has the right to the preservation of his health through sanitary and social measures relating to food, clothing, housing and medical care, to the extent permitted by public and community resources." Organization of American States, American Declaration of the Rights and Duties of Man, May 2, 1948, O.A.S. Res. XXX, reprinted in Basic Documents Pertaining to Human Rights in the Inter-American System, OEA/Ser.L/V/II.82 doc.6, rev.1 (1992). This right is available to all persons, without regard to their immigration status in a country. Id.

91. COUNCIL ON ETHICAL \& Judicial AFFAIRS, AM. MED. Ass'N, PHYSICIAN RESPONSIBILITIES FOR SAFE PATIENT DISCHARGE, CEJA Report 2-I-09, at 4 (2009).

92. Id. at 2 .

93. Statute of the Inter-American Commission on Human Rights, O.A.S. Res. 447 (IX0/79), O.A.S. Off. Rec. OEA/Ser.P/IX.0.2/80, Vol. 1 at 88, Inter-Am. Comm'n H.R, OEA/Ser.L/V/11.50 doc. 13 rev. 1 at 10 (1980), reprinted in Basic Documents Pertaining to Human Rights in the Inter-American System, OEA/Ser.L.V/II.82 doc.6, rev.1 at 93 (1992).

94. The Inter-American Court has stressed the vulnerable situation of migrants who are subject to ethnic prejudices, xenophobia and racism, which makes it difficult for them to integrate into society and leads to their human rights being violated with impunity and 
In addition to treaty-based norms, jurisprudence and advisory opinions from the Inter-American Commission (and Court) on Human Rights and the European Court on Human Rights interpreting the right to be free from extrajudicial deportation and the rights to health and life impose a duty on the United States. ${ }^{95}$

\section{STATE ACCOUNTABILITY FOR FORCED OR COERCED MEDICAL REPATRIATIONS}

From an international human rights perspective, the most challenging aspect of establishing liability in the case of forced or coerced medical repatriations lies in establishing that the United States, rather than individual hospitals or transportation companies, is responsible. It is a well-established principle under international human rights law that a state cannot insulate itself from liability for human rights abuses by stepping back and allowing private actors to violate an individual's human rights. ${ }^{96}$ For example, a state cannot

denial of access to public resources. Juridical Condition and Rights of the Undocumented Migrants, Advisory Opinion OC-18/03, Inter-Am. Ct. H.R. (ser. A) No. 18, I1 112-13 (Sept. 17, 2003). The UN General Assembly in its resolution on "Protection of Migrants" referred to "the manifestations of violence, racism, xenophobia and other forms of discrimination and inhuman and degrading treatment against migrants, especially women and children, in different parts of the world." G.A. Res. 45/166, U.N. Doc. A/RES/54/166 (Feb. 24, 2000). The resolution also stressed "the situation of vulnerability in which migrants frequently find themselves, owing, inter alia, to their absence from their State of origin and to the difficulties they encounter because of differences of language, custom and culture, as well as the economic and social difficulties and obstacles for the return to their States of origin of migrants who are non-documented or in an irregular situation." Id.

95. For example, the Inter-American Court on Human Rights issued an Advisory Opinion in which it unanimously stated that States "must take affirmative action, avoid taking measures that limit or infringe a fundamental right, and eliminate measures and practices that restrict or violate a fundamental right." Juridical Condition and Rights of the Undocumented Migrants, Advisory Opinion OC-18/03, Inter-Am. Ct. H.R. (ser. A) No. 18, I 173 (Sept. 17, 2003). According to the Court, "the right to due process of law must be recognized as one of the minimum guarantees that should be offered to any migrant, irrespective of his migratory status." Id.

96. Many provisions of the Uniform Declaration of Human Rights (UDHR) and other human rights declarations have the status of customary international law. See Hurst Hannum, The Status of the Universal Declaration of Human Rights in National and International Law, 25 GA. J. INT'L \& COMP. L. 287, 289 (1995/1996); see also M. Erin Kelly, Customary International Law in United States Courts, 32 VILL. L. REV. 1089, 1090-91 (1987) ("As a source of international law, custom refers to conduct or knowing abstention from conduct, of members of a society which is part of the legal order of that society. To become a binding rule of international law, a custom must be a practice that states follow and deem to be a legal obligation. . . The United States Supreme Court has ruled that customary international law is "part of our law, and must be ascertained and administered by the courts of justice of appropriate jurisdiction . . . ."). This customary international 
insulate itself from acts of torture if private actors carry them out with the state's acquiescence. ${ }^{97}$ Similarly, many states have interpreted the Refugee Convention to bar persecution by nonstate actors as long as the government is unwilling or unable to control the private actor. ${ }^{98}$ In this section, I explore theories for holding the United States responsible for the forced or coerced medical repatriations that are occurring.

Under international human rights law, a state is required to "respect, protect and promote" human rights. 99 Similarly, the jurisprudence of the Inter-American Commission on Human Rights

law requires that states take measures to prevent private third parties from violating individuals' human rights. U.N. Office of the High Comm'r for H.R., International Human Rights Law, http://www.ohchr.org/EN/ProfessionalInterest/Pages/InternationalLaw.aspx (last visited Jan. 28, 2012).

97. Under the Convention Against Torture (CAT) an act of torture is an act "inflicted by or at the instigation of or with the consent or acquiescence of a public official or other person acting in an official capacity." U.N. Convention Against Torture and Other Cruel, Inhuman or Degrading Treatment or Punishment, art. 1, I 1, June 26, 1987, 1465 U.N.T.S. 85. The U.N. Special Rapporteur on Torture, Nigel S. Rodley, interprets the state action requirement to be met when public officials are "unable or unwilling to provide effective protection from ill-treatment (i.e. fail to prevent or remedy such acts), including ill-treatment by non-State actors." U.N. Office of the High Comm'r for H.R., Human Rights Fact Sheet: No. 4 Combating Torture, 34 (May 2002), available at http://www.unhcr.org/refworld/publisher,OHCHR,,,4794774b0,0.html.

98. Guy S. Goodwin-Gill posits that where governments are unwilling or unable to control persecution by private nonstate actors, the Refugee Convention permits persecution, "for it does not follow that the concept is limited to the actions of governments or their agents ... no necessary linkage between persecution and government authority is formally required." GUY S. GOODWIN-GILL, THE REFUGEE IN INTERNATIONAL LAW 71.72 ( $2 \mathrm{~d}$ ed. 1996). Goodwin-Gill further adds that "there is no basis in the 1951 Convention, or in general international law, for requiring the existence of effective, operating institutions of government as a pre-condition to a successful claim to refugee status." Id. at 73-74; accord Jennifer Moore, From Nation State to Failed State: International Protection from Human Rights Abuses by Non-State Agents, 31 ColuM. HUM. RTS. L. REV. 81, 110-11 (1999); Lori A. Nessel, "Willful Blindness" to Gender-Based Violence Abroad: United States' Implementation of Article Three of the United Nations Convention Against Torture, 89 MinN. L. REv. 71, 156 (2004).

99. The Universal Declaration of Human Rights (UDHR) calls for "every individual and every organ of society" to respect, protect and promote human rights. UDHR, supra note 68 , at pmbl. Moreover, the United Nations posits that human rights include both rights and obligations: "[s]tates assume obligations and duties under international law to respect, to protect and to fulfill human rights. The obligation to respect means that States must refrain from interfering with or curtailing the enjoyment of human rights. The obligation to protect requires States to protect individuals and groups against human rights abuses. The obligation to fulfil [sic] means that States must take positive action to facilitate the enjoyment of basic human rights." U.N. Office of the High Comm'r for H.R., What are Human Rights?, http:/www.ohchr.org/en/issues/Pages/WhatareHumanRights.aspx (last visited Jan. 27, 2012). 
imposes an obligation on states to exercise due diligence to ensure that its human rights obligations are upheld. 100

Pursuant to the Inter-American Court of Human Rights decision in Velásquez Rodriguez, each state has "a legal duty to take reasonable steps to prevent human rights violations and to use the means at its disposal to carry out a serious investigation of violations committed within its jurisdiction, to identify those responsible, to impose the appropriate punishment and to ensure the victim adequate compensation." 101 Here, the failure of the United States to act with the due diligence required to protect the rights of those subject to medical repatriation by hospitals holds it responsible for the resulting human rights violations. ${ }^{102}$ As articulated by the Inter-American Court on Human Rights in Velasquez,

[a]n illegal act which violates human rights and which is initially not directly imputable to a state (for example, because it is the act of a private person or because the person responsible has not been identified) can lead to international responsibility of the state, not because of the act itself, but because of the lack of due diligence to prevent the violation or to respond to it as required by the Convention. ${ }^{103}$

100. Inter-American Court of Human Rights jurisprudence has held that "[a]n illegal act which violates human rights and which is initially not directly imputable to a State (for example, because it is the act of a private person or because the person responsible has not been identified) can lead to international responsibility of the State, not because of the act itself, but because of the lack of due diligence to prevent the violation or to respond to it as required by the Convention." Velásquez Rodríguez v. Honduras, Judgment, Inter-Am. Ct. H.R. (ser. C) No. 4, I 172 (July 29, 1988). As a consequence of this duty, "[s]tates must prevent, investigate and punish any violation ..." of rights. Id. I 166. See, e.g, Fernandes v. Brazil, Case 12.051, Inter-Am. Comm'n H.R., Report No. 54/01, OEA/Ser.L/V.II.111 doc. 20 rev. I 61(3) (2001) (where the Inter-American Commission found that the State violated its obligation to exercise due diligence to prevent, punish and eliminate domestic violence by failing to convict the perpetrator for 15 years).

101. Velásquez Rodríguez v. Honduras, Judgment, Inter-Am. Ct. H.R. (ser. C) No. 4, at II 174.

102. See, e.g., Mortlock v. United States, Case 12.543, Inter-Am. Comm'n H.R., Report No 63/08, If 94 (July 25, 2008) (holding the United States accountable under the Declaration when it "knowingly sen[t] Ms. Mortlock to Jamaica with the knowledge of her current health care regime and the country's sub-standard access to similar health for those with HIV/AIDS would violate Ms. Mortlock's rights, and would constitute a de facto sentence to protracted suffering and unnecessarily premature death").

103. Velásquez Rodríguez v. Honduras, Judgment, Inter-Am. Ct. H.R. (ser. C) No. 4, at ๆ 172. 
Specifically, as explored in greater detail below, by failing to enact laws and policies that sufficiently protect patients' rights, by inadequately enforcing those laws that do exist, and by failing to provide adequate remedies to victims of this egregious practice, the United States has arguably created an environment in which medical repatriations occur with impunity.

In the case of medical repatriations, not only are patients denied access to healthcare in the United States, they are frequently transferred to countries that cannot provide the required level of care. ${ }^{104}$ Pursuant to international human rights law, any time a country becomes a party to an international treaty, it assumes a duty to respect, protect, and fulfill human rights. ${ }^{105}$ In cases involving the right to health, the duty to respect human rights requires the state to refrain from denying or limiting equal access to health services for all persons, including undocumented immigrants. ${ }^{106}$ The duty to protect includes a duty on states to adopt legislation ensuring equal access to health care provided by third parties. ${ }^{107}$ Similarly, the duty

104. Dr. Steven Larson, a migrant health expert, described repatriation as "pretty much a death sentence in some of these cases ... I've seen patients bundled onto the plane and out of the country, and once that person is out of sight, he's out of mind." Sontag, supra note 11. There have been a number of documented reports of individuals dying or facing serious health deterioration upon their return to their country of origin following extrajudicial hospital deportations. See, e.g., Paul Harasim, Sending Patients Home, LAS VEGAS REV. J. (Aug. 23, 2009, 10:00 PM), http://www.lvrj.com/news/54286002.html (describing an eighteen-year-old patient with a "highly curable form of leukemia" who died after an Arizona hospital's transfer to a Mexican hospital); Kevin Sack, For Sick Illegal Immigrants, No Relief Back Home, N.Y. TIMES, Jan. 1, 2010, http:/www.nytimes.com/2010/01/01/health/policy/01grady.html?pagewanted=all; Office of Inspector Gen., Patient Dumping, DeP'T Health \& Human SERvs., http://oig.hhs.gov/fraud/enforcement/cmp/patient_dumping.asp (last visited Jan. 28, 2012).

105. See International Human Rights Law, UNITED NATIONS HuMAN RTS., http://www.ohchr.org/en/professionalinterest/Pages/InternationalLaw.aspx (last visited March 20, 2012) ("The obligation to respect means that States must refrain from interfering with or curtailing the enjoyment of human rights. The obligation to protect requires States to protect individuals and groups against human rights abuses. The obligation to fulfil means that States must take positive action to facilitate the enjoyment of basic human rights.").

106. Comm. on Econ. Soc. and Cultural Rights, Gen. Comment 14, 22d Sess., Apr. 25May 12, 2000, U.N. Doc. E/C.12/2000/4, I 53 (May 11, 2000) [hereinafter Gen. Comment 14].

107. Id. at I 35 (also noting that "[o]bligations to protect include, inter alia . . . to ensure that privatization of the health sector does not constitute a threat to the availability, accessibility, acceptability and quality of health facilities, goods and services .... and to ensure that medical practitioners and other health professionals meet appropriate standards of education, skill and ethical codes of conduct. States are also obliged to . . prevent third parties from coercing women to undergo traditional practices, e.g. female genital mutilation; and to take measures to protect all vulnerable or marginalized groups 
to fulfill human rights obligations should be interpreted to require states to adopt appropriate legislative, administrative, budgetary, judicial, and other measures towards the full realization of the right to health. ${ }^{108}$ Finally, the state's duties include taking measures to prevent third parties from interfering with these rights. ${ }^{109}$

The United States has enacted a health care regime that violates even the most basic protections for immigrants under international human rights law. ${ }^{110}$ Specifically, the United States provides inadequate funding, places harsh restrictions on states and hospitals that treat immigrants, and fails to properly monitor international discharges, resulting in an unregulated and underfunded grey zone that fosters nonconsensual medical repatriations. ${ }^{111}$ For example, while the United States requires federally funded hospitals to provide emergency medical treatment to all patients regardless of their immigration status, ${ }^{112}$ federal law only allows for reimbursement of certain types of emergency care for undocumented immigrants. ${ }^{113}$ Moreover, in most jurisdictions, once patients are provided with critical care and stabilized, in most jurisdictions, there is no federal reimbursement available for nonemergency treatment of undocumented patients. ${ }^{114}$ The United

of society, in particular women, children, adolescents and older persons, in the light of gender-based expressions of violence. States should also ensure that third parties do not limit people's access to health-related information and services.").

108. Id. at I 36 (clarifying that "[t]he obligation to fulfill requires States parties, inter alia, to give sufficient recognition to the right to health in the national political and legal systems, preferably by way of legislative implementation, and to adopt a national health policy with a detailed plan for realizing the right to health. ... Further obligations include the provision of a public, private or mixed health insurance system which is affordable for all ....”.).

109. See Sabine Michalowski, Sovereign Debt and Social Rights-Legal Reflections on a Difficult Relationship, 8 HUM. RTS. L. REV. 35, 40.41 (2008) (noting that the failure of States to provide essential primary healthcare to the needy may amount to a violation).

110. For example, the United States' restriction on funding long-term health care needs of all immigrants except those that have been lawful permanent residents for over five years may be in contravention of Article 5(iv) of the ICERD, supra note 70 (guaranteeing the right to public health to everyone without regard to national origin), and Article 25(1) of the UDHR, supra note 68 (guaranteeing that "[e]veryone has the right to a standard of living adequate for the health and well-being of himself and his family, including food, clothing, housing and medical care and necessary social services").

111. Currently, no federal or state laws directly address this issue. See Wolpin, supra note 10 , at 152 .

112. EMTALA, 42 U.S.C. $\S \S 1395 \mathrm{dd}(\mathrm{B})(1)(\mathrm{A})$-(B) (2011).

113. 42 U.S.C. $\S 1396 \mathrm{~b}(\mathrm{v})(2)(\mathrm{A})(2011)$.

114. 42 U.S.C. $\S \S 1320 \mathrm{~b}-7(\mathrm{a})(1)$, (d), (f). A legislative overhaul of the United States healthcare system in 2010 did not provide opportunities for government-funded healthcare for undocumented immigrants. See Patient Protection and Affordable Healthcare Act, Pub. L. No. 111-148, 124 Stat. 119 (2010). Undocumented immigrants are also generally not eligible for state-funded Medicaid coverage except when such services 
States' failure to provide adequate funding for the serious health care needs of undocumented and many lawful permanent resident immigrants $^{115}$ has resulted in a gap in human rights protection and an environment in which some hospitals repatriate immigrants with seeming impunity.

In addition, the United States has failed to adequately mandate reporting for hospitals engaged in international discharges ${ }^{116}$ or to provide appropriate remedies for victims of this egregious practice. Under federal law, the only remedy available to individuals who suffer personal harm as a result of a hospital's violation of the law is to commence a civil action against the hospital to obtain those damages available for personal injury under the law of the state in which the hospital is located.117 However, filing a personal injury suit is nearly impossible for most patients who have been extrajudicially deported because of their inability to reenter the country to obtain counsel and to access the experts needed to prepare a successful case. ${ }^{118}$ In addition, for the families of deceased victims like the nineteen-year-old girl who died after a medical repatriation to Mexico, ${ }^{119}$ a civil suit is no consolation, especially when the situation could have been prevented in the first place.

Furthermore, the failure of the United States to exercise "due diligence" occurs in a context in which the United States is independently aware of the ongoing practice and is turning a blind eye

are necessary for the treatment of an emergency medical condition and the individual otherwise meets the eligibility requirements for Medicaid. 42 U.S.C. $\$ \S 1396 \mathrm{~b}(\mathrm{v})(2)(\mathrm{A})$-(B).

115. Lawful permanent residents are ineligible for Medicaid coverage for five years after obtaining lawful permanent residence. Personal Responsibility and Work Opportunity Reconciliation Act of 1996, 8 U.S.C. $\$ 1613$ (2011).

116. Hospitals, as a condition of participation in Medicare, are required to develop discharge plans that ensure patients receive the appropriate post-hospital care that meets their needs. Dep't Health \& Human Serv. Conditions of Participation for Hospitals Rule, 42 C.F.R. $\S 482.43$ (2011); see also 42 U.S.C. $\S 1395 \mathrm{dd}(\mathrm{c})$ (2011). However, the U.S. Department of Health and Human Services, which is responsible for overseeing hospitals' compliance with discharge rules, does not require hospitals to maintain uniform records on patient discharges and transfers or report whether patients consent to their discharges or transfers to another facility. Jennifer M. Smith, Screen, Stabilize, and Ship: EMTALA, U.S. Hospitals, and Undocumented Immigrants (International Patient Dumping), 10 HOUS. J. HEALTH L. \& POL'Y 309, 346-47 (2010).

117. 42 U.S.C. $\S 1395 \mathrm{dd}(\mathrm{d})(2)(\mathrm{A})$; see also Smith, supra note 116 , at 325 .

118. This point is reinforced by the fact that there is only one known legal challenge to medical repatriation. See Montejo v. Martin Mem'l Med. Ctr., 874 So. 2d 654 (Fla. Dist. Ct. App. 2004).

119. See Case of Anonymous, supra note 21. 
to it. ${ }^{120} \mathrm{~A}$ state is responsible for the actions of private parties when a violation of an individual's rights occurs "with the support or acquiescence of the government, or when the state has allowed the act to take place without taking measures to prevent it or punish those responsible."121 Here, ICE has urged its officers to exercise their discretion not to initiate removal proceedings when "the existence of extreme disease or impairment .. . makes . . . removal highly unlikely." ${ }^{22}$ However, consulates report that U.S. government officials from DHS, and even members of Congress, have pressured them to release the travel documents that are required for repatriation of patients who have not consented to their transfer and who, upon further investigation, were not stable enough for transfer. ${ }^{123}$ Consequently, in what constitutes a clear violation of the Declaration, the U.S. government is acquiescing to the practice and ignoring its legal responsibility to protect the health and due process rights of immigrants. Under international human rights law, the United States has an obligation to affirmatively protect the human rights of all individuals within its national territory, ${ }^{124}$ regardless of their immigration status. ${ }^{125}$

Human rights law presents an opportunity for moving the debate over medical repatriation away from its current focus on cost to the hospitals and the unlawful immigrant status of the patients. It opens the debate to include discussion of the basic human rights that are owed to all people, regardless of immigration status. It also provides a potential mechanism for holding the state accountable for what might

120. A recent New York Times article quoted Kelly Nantel, a spokeswoman for ICE saying that ICE "does not get involved in repatriations undertaken by hospitals." Sontag, supra note 17.

121. Velásquez Rodríguez v. Honduras, Judgment, Inter-Am. Ct. H.R. (ser. C) No. 4, 9 173 (July 29, 1988).

122. ICE urges its agents in the Office of Detention and Removal Operation (DRO) to use their "favorable" prosecutorial discretion when "the existence of extreme disease or impairment ... makes detention problematic and/or removal highly unlikely." Memorandum from John P. Torres, Director, U.S. Immigration and Customs Enforcement, to Assistant Directors, Deputy Assistant Directors, and Field Office Directors, U.S. Immigration and Customs Enforcement on Discretion in Cases of Extreme or Severe Medical Concerns (Dec. 11, 2006), http://www.ice.gov/doclib/foia/dro_policy_memos/discretionincasesofextremeorseveremedicalcon cerndec112006.pdf.

123. Interview with John de Leon, Esq., Chavez \& De Leon, P.A., in Miami, Fla. (Sept. 12, 2010).

124. Juridical Condition and Rights of the Undocumented Migrants, Advisory Opinion OC-18/03, Inter-Am. Ct. H.R. (ser. A) No. 18, ๆT 112-13 (Sept. 17, 2003).

125. See Theodor Meron, HUMAN RIGHTS AND HUMANITARIAN NoRMS AS CUSTOMARY INTERNATIONAL LAW 139 (1989) (discussing the obligation of states to effectively protect human rights). This obligation of effectiveness is made explicit in the American Convention on Human Rights, Nov. 22, 1969, arts. 1-2. 
otherwise be seen as anomalous bad acts by hospitals or private transportation companies. However, human rights law, like international law in general, continues to suffer from an overarching deference to the state on issues such as immigration policy that implicate notions of sovereignty. As one scholar has noted:

[i]nternational law has not developed a language that is able to address the personal interests that are affected whenever the state bases its claims on sovereignty territorial form. As a result, whenever the state presents an issue-such as immigration-as an urgent threat to its territorial sovereignty, international law falls back on the classic legal discourse designed to address interstate violence, which merely emphasizes the integrity of territorial boundaries, and in which personal interests remain inarticulable. ${ }^{126}$

\section{What Does the Case Study of Medical Repatriations Tell us ABOUT GLOBALIZATION AND MIGRATION OF UNDOCUMENTED WORKERS?}

The graphic depiction of injured migrant laborers being ushered out of hospitals under cover of darkness through back doors intended for garbage disposal, speaks volumes to the need for more humane immigration and health care regimes and the dangers inherent in privatization of governmental functions. But on a broader level, the practice of medical repatriation is symptomatic of a global regime that dehumanizes migrant workers on many levels. In the case of Mexican migrants, these forced or coerced medical repatriations conjure up disturbing similarities to the so-called "voluntary repatriation" program of the $1930 \mathrm{s.}{ }^{127}$ At that time, in an effort to return U.S. jobs to "true Americans," the government forcibly repatriated approximately one million persons of Mexican descent, including U.S. citizens. ${ }^{128}$ Although the medical repatriations that are occurring today are not of the same magnitude as the 1930 s repatriations, Mexicans-and other Latin

126. Galina Cornelisse, Immigration Detention and the Territoriality of Universal Rights, in The Deportation Regime: Sovereignty, SPACE, AND THE FreEdom of MOVEMENT 101, 113-14 (Nicholas De Genova \& Nathalie Peutz eds., 2010).

127. For a thorough and compelling study of the Mexican repatriation program in the 1930's, see generally Francisco E. BALDERRAMA \& RAYMOND RODRIGUEZ, DECADE OF BETRAYAL: MEXICAN REPATRIATION IN THE 1930'S (1996).

128. See Kevin R. Johnson, The Forgotten "Repatriation" of Persons of Mexican Ancestry and Lessons for the "War on Terror", 26 PACE L. REV. 1, 4 (2005) (noting that approximately sixty percent of the persons removed to Mexico during the Great Depression were U.S. citizens of Mexican descent). 
American migrants-are once again being coerced into leaving the United States for economic reasons. As in the Great Depression Mexican migration program, the repatriations of today are carried out by local agencies, and little public attention is garnered. ${ }^{129}$

Migrant workers in the United States have aptly been referred to as "indispensable, disposable workers." 130 The inherent contradiction in treating indispensable workers as if they were disposable is reflected in domestic labor and immigration laws in the United States. After the U.S. Supreme Court's ruling in Hoffman Plastic Compounds v. NLRB, ${ }^{131}$ undocumented workers that seek redress for violation of their guaranteed labor rights have found themselves with rights, but no remedies. ${ }^{132}$ Just as there are no remedies for violations of labor laws for undocumented workers, there is no cure when undocumented migrants suffer serious injuries or illnesses.

Under U.S. immigration law, the large pool of undocumented immigrants is placed within categories with only a few subgroups deemed worthy of protection principally as "victims," and the majority relegated to the "disposable worker" category. ${ }^{133}$ For example, under current U.S. immigration law, certain subgroups of laborers or migrants are eligible for lawful immigration status because they are perceived as victims who have been exploited at the hands of traffickers, employers,

129. In the 1930s "local agencies, saddled with mounting relief and unemployment problems, used a variety of methods to rid themselves of 'Mexicans': persuasion, coaxing, incentive, and unauthorized coercion. Special railroad trains were made available, with fare at least to the Mexican border prepaid; and people were often rounded up by local agencies to fill carloads of human cargo. In an atmosphere of pressing emergency, little if any time was spent on determining whether the methods infringed upon the rights of citizens." Id. at 5 (citation omitted).

130. See Gregory Rodriguez, Wanted: Indispensible, Disposable Workers, L.A. TIMES, Apr. 30, 2007 (noting that farmers in Colorado were contracting with the State Correctional Department to line up prisoners to pick their crops in anticipation of Colorado's anti-immigration laws deterring necessary migrant labor).

131. The Supreme Court's 5-4 ruling severely compromised the National Labor Relations Board's ability to protect undocumented workers that are subject to labor violations. The majority held that the Immigration Reform and Control Act of 1986 precluded the National Labor Relations Board from ordering an employer to pay a backpay award when it violates the guaranteed labor rights of an undocumented worker. Hoffman Plastic Compounds, Inc. v. NLRB, 535 U.S. 137 (2002).

132. See, e.g., Robert I. Correales, Did Hoffman Plastic Compounds, Inc., Produce Disposable Workers?, 14 LA RAZA L. J. 104 (2003).

133. As Nicholas De Genova has aptly observed, "unlike the refugee, whose naked humanness elusively tends to be figured as statelessness, the deportable alien makes her obtrusive appearance almost always fully clad, in her work clothes." Nicholas De Genova, The Deportation Regime: Sovereignty, Space, and the Freedom of Movement, in THE DEPORTATION REgime: SOVEREIGNTY, SPACE, AND THE FREEDOM OF MOVEMENT 33, 48 (Nicholas De Genova \& Nathalie Peutz eds., 2010). 
or spouses. ${ }^{134}$ For those migrant laborers that fit into one of these subgroups, lawful immigration status may be available in exchange for assisting the government in a prosecution or in order to restore the victim to the status that she would have enjoyed had there not been abuse or unlawful activity. ${ }^{135}$

While the T, U, and Violence Against Women Act (VAWA) visas offer significant protection to particular migrants, the vast majority of undocumented migrants do not fit within these narrow categories. Congress could create additional visa categories, or modify existing ones, to allow for a broader range of undocumented migrants who have been injured at work to qualify for lawful immigration status and be able to pursue health care. For example, a new visa category could be modeled on the existing $\mathrm{T}, \mathrm{U}$, and VAWA visas and allow for lawful immigration status in exchange for the worker's assistance in prosecuting the employer for violations of labor, employment, or safety codes. ${ }^{136}$

134. $\mathrm{T}$ visas, created by the Trafficking Victims Protection Act of 2000 (TVPA), are intended to protect individuals who are the victims of human trafficking. $T$ visas allow victims of severe forms of trafficking in persons to remain in the United States and assist federal authorities in the investigation and prosecution of human trafficking cases. According to U.S. government estimates, "45,000 to 50,000 women and children are trafficked into the United States annually, and are trapped in modern-day slavery-like situations such as forced prostitution." Press Release, Dep't of Justice, Department of Justice Issues T Visa to Protect Women, Children and All Victims of Human Trafficking (Jan. 24, 2002), available at http://www.justice.gov/opa/pr/2002/January/02_crt_038.htm. See 8 U.S.C. $\S 1101(\mathrm{a})(15)(\mathrm{T})$. U visas are similarly available for victims of certain crimes who are assisting law enforcement in prosecution. U visas allow immigrants who have endured substantial mental or physical abuse and who are willing to cooperate with law enforcement officials to work legally and stay in the United States for up to four years while applying for permanent residence. 8 U.S.C. $\S \S 1101(a)(15)(U), 1184(p)$. For a description of the U visa program, see Katherine Ellison, A Special Visa Program Benefits Abused Ilegal Immigrants, N.Y. TIMES, Jan. 8, 2010. Visas are also available to battered spouses, children and parents of U.S. citizens or permanent residents under the Violence Against Women Act (VAWA). VAWA allows certain spouses, children and parents of U.S. citizens and permanent residents (green card holders) to file a petition for themselves without the abuser's knowledge, Battered Spouses, Children \& Parents, U.S. CITIZENShIP \& IMMIGRATION SERV., http:/www.uscis.gov/portal/site/uscis/menuitem.eb1d4c2a3e5b9ac89243c6a7543f6d1a/?vgnex toid=b85c3e $4 \mathrm{~d} 77 \mathrm{~d} 73210 \mathrm{VgnVCM} 100000082 \mathrm{ca} 60 \mathrm{aRCRD} \& v g n e x t c h a n n e l=b 85 \mathrm{c} 3 \mathrm{e} 4 \mathrm{~d} 77 \mathrm{~d} 7321$ 0VgnVCM100000082ca60aRCRD (last visited Jan. 27, 2012).

135. See infra note 126.

136. Professor Rathod has argued that, in order for undocumented workers to be able to report workplace violations without fear of employer retaliation and reporting to ICE, the Occupational Safety and Health Administration [OSHA] should enter into a Memorandum of Understanding with the Department of Homeland Security. Such a Memorandum of Understanding would prohibit ICE from conducting a workplace raid or engaging in worksite enforcement actions in any worksite that is being investigated by OSHA for health and safety violations. Jayesh M. Rathod, Immigrant Labor and the Occupational 
Alternatively, Congress or DHS could specify which agencies must serve as certifying agencies for $U$ visas ${ }^{137}$ or the agencies that are already engaged in the $U$ visa certification process could expand the scope of their jurisdiction in order to protect against a greater number of workplace violations. ${ }^{138}$ For example, in 2007, seven years after Congress enacted the legislation to establish the $U$ visa, ${ }^{139}$ the DHS promulgated regulations that included the Department of Labor (DOL) and the Equal Employment Opportunity Commission (EEOC) as agencies that were empowered to certify a victim's helpfulness in investigating or prosecuting a violent crime, as required for a $U$ visa. ${ }^{140}$ Although the regulations clarified that the EEOC and the DOL were included within the ambit of federal and state agencies that could provide certifications for $U$ visas, it was left to the agency itself to determine whether and how it would certify U visas. ${ }^{141}$ It was not until

Safety and Health Regime: Part I: A New Vision for Workplace Regulation, 33 N.Y.U. REV. L. \& SOC. CHANGE 479, 482, 555 (2009) (arguing that structural features of the workplace safety and health regime, including rulemaking, inspection, and enforcement, have historically disadvantaged immigrant workers and prevented OSHA from fulfilling its statutory mandate "to assure so far as possible [for] every working man and woman in the Nation safe and healthful working conditions").

137. In the Victims of Trafficking and Violence Protection Act, Congress did not specify which agencies would be responsible for providing the certifications needed for $U$ visas. Pursuant to the legislation, Congress stated that "[t]he petition filed by an alien under section 101(a)(15)(U)(i) shall contain a certification from a Federal, State, or local law enforcement official, prosecutor, judge, or other Federal, State, or local authority investigating criminal activity described in section 101(a)(15)(U)(iii)." Victims of Trafficking and Violence Protection Act of 2000, Pub. L. No. 106-386, 114 Stat. 1464 (2000).

138. When the DHS finally issued regulations to implement the $U$ visas that Congress had created seven years prior, the DHS named the DOL and EEOC as examples of appropriate law enforcement agencies to engage in $U$ visa certifications but it remains up to the agency to determine how to proceed. See New Classification for Victims of Criminal Activity; Eligibility for " $U$ " Nonimmigrant Status, 72 Fed. Reg. 53,014 (Sept. 17, 2007) (to be codified at 8 C.F.R. pts. 103, 212, 214, 248, 274(a), 299), available at http://apps.americanbar.org/domviol/tip/trainings/Immigration\%20Remedies\%20for\%20Tr afficking\%20Victims\%20Workshop/U\%20Visa\%20Regs\%20.

\%20Fed.\%20Register\%209.17.2007.pdf.

139. See Victims of Trafficking and Violence Protection Act of 2000, Pub. L. 106-386, § 1513, 114 Stat. 1464, 1533-37 (2000), as amended by Violence Against Women and Department of Justice Reauthorization Act of 2005 (VAWA 2005), Pub. L. No. 109-162, 119 Stat. 2960 (2006); Violence Against Women and Department of Justice Reauthorization Act-Technical Corrections, Pub. L. No. 109-271, 120 Stat. 750 (2006).

140. New Classification for Victims of Criminal Activity; Eligibility for " $U$ " Nonimmigrant Status, supra note 138.

141. Id 
2011 that the DOL announced it would commence certifying U visas, notwithstanding its ability to do so as of 2007.142

While the DOL decision to begin assisting in the $U$ visa process is significant, it has confined its own jurisdiction to certifications in criminal cases arising through its Wage and Hour Division. ${ }^{143}$ Furthermore, the DOL has decided to limit the crimes that it will certify to involuntary servitude, peonage, trafficking, obstruction of justice, and witness tampering. ${ }^{144}$ Although the DOL could certify a broader range of crimes, including those relating to occupational safety and health, it elected not to do so. If the DOL were to certify $U$ visas in cases involving Occupational Safety and Health Administration (OSHA) crimes, undocumented workers that sustained serious injuries due to unsafe work environments would be able to pursue lawful immigration status in exchange for assisting in the prosecution of the employer. ${ }^{145}$ Alternatively, Congress could amend its implementing legislation to list particular agencies that must assist in the certification of $U$ visas. Finally, DHS could exercise its prosecutorial discretion to not deport a migrant laborer who is seriously injured and is in need of ongoing medical care. ${ }^{146}$

Unfortunately, in the case of forced or coerced medical repatriations, lawful immigration status or a decision not to deport an injured migrant would not necessarily be sufficient to curb the unlawful practice. First,

142. See U.S. Labor Department Announces Protocols for Certifying U Visa Applications, U.S. DEP'T LABOR (Apr. 28, 2011), http://www.dol.gov/opa/media/press/whd/whd20110619.htm.

143. See NaT'l EMPloyment LaW PROJeCt, PROTECTION FOR IMMigrant Victims of WORKPLACE CRIMES: UNITEd States DEPARTMENT OF LABOR PROTOCOL FOR U Visa CERTIFICATION, May 3, 2011, available at http://www.nelp.org/page//Justice/2011/ProtectionforImmigrantVictimsofWorkplaceCrimes-

Uvisas.pdf?nocdn $=1 \% 20 \% 20$ ?nocdn $=1$ ("DOL's regulatory authority to certify U visas extends agency-wide (including key subagencies such as OSHA), but it appears to have elected to make certifications only in the context of Wage and Hour investigations and to have excluded other DOL-administered laws.").

144. Id.

145. However, the OSH Act is woefully inadequate in its ability to provide meaningful protection to workers due to its weak criminal provisions and monetary sanctions. The Assistant Secretary for Occupational Safety and Health at the Department of Labor, David Michaels, has testified that "Because OSHA's criminal penalties are considered misdemeanors Federal prosecutors often regard these cases as a poor use of scarce time and resources. Since passage of the OSH Act in 1970 fewer than 100 cases have been prosecuted while more than 300,000 workers have died from on-the-job injuries." Testimony of David Michaels Assistant Secretary for Occupational Safety and Health U.S. Dep't of Labor Before the Sub Committee on Workforce Protections, The Committee on Education and Labor, U.S. House of Representatives (2010), available at http://www.osha.gov/pls/oshaweb/owadisp.show_document?p_table=TESTIMONIES\&p_id $=1062$.

146. See Memorandum from John P. Torres, supra note 60 and accompanying text. 
not all immigrants who have lawful immigration status qualify for Medicaid funding. Most notably, even lawful permanent residents are not entitled to Medicaid for the first five years after obtaining this status. ${ }^{147}$ Second, because the deportations at issue here are being carried out extrajudicially by private actors, rather than by federal immigration authorities, there is no reason to trust that unscrupulous hospitals or private transport companies would not still "dump" injured immigrants back in their home countries, particularly if the costs of ongoing treatment did not qualify for governmental reimbursement. ${ }^{148}$

Because lawful immigration status alone would not address the root causes that fuel medical repatriations, the government must enact a more humane health care system and take affirmative steps to ensure that private actors do not violate human rights. A human rights approach to addressing issues that are at the root of the exploitation of immigrant labor-including medical repatriation-would necessitate a broader examination of all of the interconnected factors that lead to migration and make migrants vulnerable to human trafficking or exploitation. ${ }^{149}$ For example, if there were safer migration channels and

147. Pursuant to the Personal Responsibility and Work Opportunity Reconciliation Act of 1996 (PRWORA), lawful permanent residents are excluded from eligibility for most federal public benefits, including Medicaid, for the first five years after obtaining permanent residency. 8 U.S.C. $\S 1613$ (2011). However, some individual states continue to provide health benefits to immigrants that are considered to be "PRUCOL" (Permanently Residing Under Color of Law). Clearly, injured migrants in those states would stand a much greater chance of receiving ongoing medical care. See, e.g., ClaUdia SCHLOSBERG, THE ACCESS

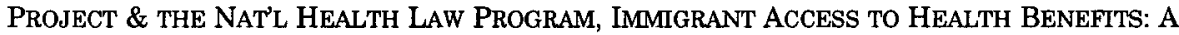
RESOURCE MANUAL 11-12, 31 (1999-2000), http://www.accessproject.org/ downloads/Immigrant_Access.pdf (explaining that "many states that had programs in place prior to the welfare law continued to fund them, and some have committed new funds to cover additional initiatives ... States with the most extensive coverage include California, Washington, Hawaii, Connecticut, Massachusetts, Rhode Island, Minnesota, New Jersey, New York, Pennsylvania, and Wisconsin"). The state of New York, for example, allows for welfare benefits, including Medicaid, for PRUCOL persons. DEP'T OF HEALTH, CITTZENSHIP and ALIEN Status Requirements For the MediCaid Program (Oct. 26, 2004), http://www.health.state.ny.us/health_care/medicaid/publications/docs/adm/04adm-7.pdf.

148. In fact, hospitals have forcibly repatriated even lawful permanent residents and U.S. citizens with serious medical conditions. For example, see the case of Antonio Torres, a nineteen-year-old legal immigrant who was forcibly repatriated to Mexico after injuries from a car accident left him comatose and dependent on a ventilator. Sontag, supra note 17. In another example, an Arizona hospital unsuccessfully moved to transfer Elliott Bustamante, a sick infant, to Mexico over the mother's opposition. The infant was an American citizen born with Down's Syndrome. Id.

149. The myriad of factors that contribute to migration include: poverty, injustice, persecution, armed conflict and lack of opportunities in the home country, as well as the need for inexpensive labor in industrialized countries and the opportunity that migration presents for workers to send remittances from the host country. See, e.g., The Root Causes 
jobs with good working conditions, people would migrate with fewer chances of exploitation, and they would be more likely to get decent and safe jobs and reduce the likelihood that their human rights would be violated. ${ }^{150}$

A human rights-based approach to migration would also entail a reconceptualization of the inherent value and dignity of migrants and migrant laborers, regardless of immigration status. Medical repatriation is perhaps the most extreme example of a global perception that migrant workers are disposable. But examples abound of situations around the world in which migration and labor policies result in the denial of migrant laborers' most fundamental human rights. ${ }^{151}$ For example, when conflict erupted in Libya during the "Arab Spring," the sub-Saharan migrant laborers who had been working in Libya before the conflict remained trapped in hiding, waiting for someone to rescue them. They camped out in substandard conditions, too fearful to move, because they faced routine persecution from both the forces who were aligned with former Libyan President Muammar Gaddafi and those fighting to over throw him. ${ }^{152}$ Because Gaddafi had used African militia to suppress and brutalize his opponents, all sub-Saharan migrants were viewed by the rebels as potential pro-Gaddafi forces and were subjected to physical abuse, torture, and killings. ${ }^{153}$ At the same time, the pro-

of Migration, MD. CATH. CoNF., http://www.mdcathcon.org/immigrationrootcauses (last visited Jan. 25, 2012).

150. Rebecca Napier-Moore et al., Beyond Borders: Exploring Links Between Trafficking and Migration 25 (Global Alliance Against Traffic in Women, Working Paper Series 2010), http://www.gaatw.org/publications/WP_on_Migration.pdf.

151. In the context of the European Union, Nathalie Peutz and Nicholas De Genova note that the lack of a comprehensive migration policy (leading to clandestine migration movements) combined with the EU's externalization of its borders (resulting in migrants being labeled as "illegal" before they even cross EU borders), has led to the current illegalized image of migration. According to Peutz and De Genova, the EU policy expects migrants to nevertheless circulate through its territories and thus dedicates its resources to the regulation of the "temporality -and thus the ultimate disposability-of migrant labor." Nathalie Peutz \& Nicholas De Genova, Introduction to The DePORTATION ReGIME: SOVEREIGNTY, SPACE, AND THE FREEDOM OF MOVEMENT, supra note 126, at 1,12 . The authors rely on the "excessive and utterly avertable fatalities that occur routinely as migrant bodies wash up on shores or perish in desert crossings" as proof that the sovereign power to regulate and restrict human movement is actually "the imposition of a power over life itself." Id. at 13.

152. David D. Kirkpatrick \& Scott Sayare, Libyan War Traps Poor Immigrants at Tripoli's Edge, N.Y. TIMES, Mar. 7, 2011, at A1.

153. See, e.g. David D. Kirkpatrick, Libyans Turn Wrath on Dark-Skinned Migrants, N.Y. TIMES (Sept. 4, 2011), http://www.nytimes.com/2011/09/05/world/africa/ 05migrants.html?pagewanted=all (documenting that many Libyans were turning their wrath against sub-Saharan African migrants, imprisoning hundreds for the crime of fighting as missionaries for Gaddafi, absent any evidence other than the color of their 
Gaddafi forces saw the sub-Saharan migrants as easy prey to beat and rob. Most troubling is that no country made any efforts to rescue these refugees, reinforcing the notion that migrant laborers are disposable or expendable and that there are no human rights obligations owed in return for their labor. The host country, while benefitting from all the migrant labor in peaceful times, devalues migrant labor in times of political or economic turmoil and leaves them in peril.

Other countries are routinely criticized for their systematic mistreatment of migrant laborers. For example, the Dominican Republic is notorious for its mistreatment of Haitian laborers:

"We do all the work, but we have no rights," said Victor Beltran, one of about 150 Haitian immigrants, most of them barefoot and dressed in rags, who had taken refuge in a rickety old barn. "We do all the work, but our children cannot go to school. We do all the work, but our women cannot go to the hospital." "We do all the work," he said, "but we have to stay hidden in the shadows."154

But increasingly, other relatively "immigrant-friendly" countries, including the United States, are taking the same inhumane approach to migrants. Furthermore, the immigration regime in the United States is fraught with inconsistencies. For example, as noted above, there is a greater willingness to protect victims of human trafficking than to protect undocumented migrants that are catastrophically injured at work and in need of medical care. In many cases, the distinction between trafficking victims and desperate migrants in search of work is an artificial one. As illustrated by the recent exodus of migrants from Libya to Lampedusa Island off of Italy, migrants that are being pushed back by sea are often returned to their traffickers. ${ }^{155}$

skin); Double Tragedy for sub-Saharan Africans, FIDH (June 29, 2011), http://www.fidh.org/Double-tragedy-for-Sub-Saharan,9840 ("[t]he evidence gathered by the FIDH mission points to widespread and systematic abuses and racially motivated violence targeting Sub-Saharan Africans in Eastern Libya.").

154. Ginger Thompson, Immigrant Laborers from Haiti are Paid With Abuse in the Dominican Republic, N.Y. TIMES, Nov. 20, 2005, http://www.nytimes.com/2005/11/20/ international/americas/20dominican.html.

155. See Pushbacks to Libya, EUR. CoUNCI ON Refugees \& EXILes (May 20, 2010), http://www.ecre.org/topics/areas-of-work/access-to-europe/88-pushbacks-to-libya.html;

Memorandum of Understanding Between Italy and Libyan NTC, MIGRANTS AT SEA BLOG (June 20, 2011, 2:11 P.M.), http://migrantsatsea.wordpress.com/2011/06/20/memorandum-ofunderstanding-between-italy-and-libyan-nct; Italy Signs Migration Agreement with Libyan Rebels, TIMESOFMALTA.COM (June 20, 2011, 12:35 P.M.), http://www.timesofmalta.com/ articles/view/20110620/local/italy-signs-migration-agreement-with-libyan-rebels. 371604 . 
As pointed out by the U.N. Special Rapporteur on Migrants Rights after his visit to the United States in 2007, "the United States lacks a clear, consistent, long-term strategy to improve respect for the human rights of migrants." 156 The Special Rapporteur concluded that, "[a]lthough there are national laws prohibiting discrimination, there is no national legislative and policy framework implementing protection for the human rights of migrants against which the federal and local programmes and strategies can be evaluated to assess to what extent the authorities are respecting the human rights of migrants." 157

Because the United States has not implemented a comprehensive and coordinated national policy based on clear international obligations, it is not adhering "to its international obligations to make the human rights of the more than 37.5 million migrants living in the country a national priority." 158 As specified by the Special Rapporteur, there should be a federal agency that is charged solely with protecting the human rights of migrants. Such a national body would truly represent the voices and concerns of the migrant population and could address underlying causes of migration and the human rights concerns of migrants within the United States. ${ }^{159}$

One way that the United States could promote this type of cohesive policy toward migrant workers is to ratify the International Convention on the Protection of the Rights of All Migrant Workers and Members of their Families (Migrant Worker Convention). ${ }^{160}$ However, while the Migrant Worker Convention is considered to be one of the nine core U.N. Conventions, very few states have ratified it and those that have done so tend to be the migrant-sending, rather than migrant-receiving ones. ${ }^{161}$

The primary objective of the Migrant Worker Convention is straightforward: to protect migrant workers and their families from

156. Promotion and Protection Report, supra note 47, at 2.

157. Id.

158. Id. at 3 . Such a national policy should recognize that, with the exception of certain rights relating to political participation, migrants are entitled to enjoy nearly all the same human rights protections as citizens, including an emphasis on meeting the needs of the most vulnerable groups. Id.

159. Id.

160. United Nations International Convention on the Protection of the Rights of All Migrant Workers and Members of Their Families, Dec. 18, 1990, 2220 U.N.T.S. 93 [hereinafter Migrant Workers Convention].

161. Lori A. Nessel, Human Dignity or State Sovereignty?: The Roadblocks to Full Realization of the UN International Convention on the Protection of the Rights of All Migrant Workers and Members of Their Families, in RESEARCH HANDBOOK ON MIGRATION AND INTERNATIONAL LAW (V. Chetail ed., forthcoming 2012). 
exploitation and violation of their human rights. ${ }^{162}$ While there are a number of international human rights treaties and conventions that cover migrant workers in particular contexts, the Migrant Worker Convention is the only one that addresses migrant workers and their families as a particular group in need of protection. ${ }^{163}$ The Migrant Worker Convention offers a multitiered set of rights depending on the circumstance of the migrant worker or family member. First, it sets forth a core set of fundamental human rights that are applicable to all migrant workers and members of their families, regardless of immigration status. ${ }^{164} \mathrm{Next}$, it provides for a more robust set of rights that is only applicable to migrant workers and members of their families with lawful immigration status in the receiving nation. ${ }^{165}$ Finally, it provides specific rights for particular groups of migrant workers, such as frontier workers, seasonal workers, project-tied workers, or self-employed workers. ${ }^{166}$ In addition to the groupings of rights, the Migrant Worker Convention also provides broad antidiscrimination provisions and a section aimed at promoting "sound, equitable, humane and lawful conditions" related to international migration. ${ }^{167}$

While ratification of the Migrant Worker Convention would provide a more holistic approach to analyzing the duties owed to migrant workers, the Convention prioritizes the state's right to control its borders over its duty to protect the human rights of undocumented migrants. 168 Unfortunately, then, in cases involving medical

162. Migrant Worker Convention, Dec. 18, 1990, 2220 U.N.T.S. 93, pmbl. (affirming the vulnerability and lack of sufficient existing human rights protections for migrant workers and their families and asserting, "the need to bring about the international protection of the rights of all migrant workers and members of their families, reaffirming and establishing basic norms in a comprehensive convention which could be applied universally").

163. See, e.g., Antoine Pécoud \& Paul de Guchteneire, Migration, Human Rights and the United Nations: An Investigation Into the Obstacles to the UN Convention on Migrants Workers' Rights, 24 WINDSOR Y.B. ACCESS JUST. 241, 241-42 (2006) ('It represents the most comprehensive international treaty protecting migrants' rights . . ..").

164. See Migrant Workers Convention, supra note 160 , at arts. 8-35.

165. Id. at arts. 36-56.

166. Id. at arts. 57-63.

167. Id. at arts. 64-71.

168. For example, Article 35 of the Migrant Worker Convention states "[n]othing in the present part of the Convention shall be interpreted as implying the regularization of the situation of migrant workers or members of their families who are non-documented or in an irregular situation or any right to such regularization of their situation." See also Article 68 stating "[s]tate parties, including States of transit, shall collaborate with a view to preventing and eliminating illegal or clandestine movements and employment of migrant workers in an irregular situation." 
repatriation of undocumented migrants, the Migrant Worker Convention might not actually protect the injured worker. ${ }^{169}$

In the instance of forced or coerced medical repatriations, the migrants at risk tend to be largely from Mexico and Central America. This suggests that a bilateral or regional approach might be worth exploring as efforts that focus on improving wages and working conditions in the home country will likely reduce migration. ${ }^{170}$ For years, economists have maintained that the best long-term strategy for reducing migration is the improvement of economic opportunities in the sending countries. ${ }^{171}$ Similarly, a bilateral or regional approach that focuses on improving health care in Mexico and Central America would help to alleviate the need for injured migrants to receive services in the United States.

Unfortunately, bilateral solutions to migration have been unusual for a number of reasons. First, immigration regulation is seen as a domestic matter and a foundational principle of international law is deference to state sovereignty over domestic matters. Second, migrantreceiving and migrant-sending countries often have inconsistent interests when migration is at issue. Third, migration flow between contiguous territories tends to be one-way so migration negotiations are not carried out on a level playing field. Fourth, domestic migration policy tends to be quite complex. ${ }^{172}$

\section{CONCLUSION}

Approaching migration from a human rights framework is essential to establishing a set of reliable and consistent principles with which to address issues affecting migrant laborers, including medical

169. Nessel, supra note 161. But see Beth Lyon, The Unsigned United Nations Migrant Worker Rights Convention: An Overlooked Opportunity To Change The "Brown Collar" Migration Paradigm, 42 N.Y.U. J. INT'L L. \& POL. 389 (2010) (arguing that, despite its shortcomings, ratification of the Migrant Workers Convention would nevertheless inject much-needed human rights discourse into the dialogue on migrant labor rights issues).

170. For example, recent studies suggest that the fewer Mexicans are migrating to the United States due to both improved conditions in Mexico and the worsening economy in the United States. See Damien Cave, Better Lives for Mexicans Cut Allure of Going North, N.Y. TIMES, July 6, 2011, http://www.nytimes.com/interactive/2011/07/06/world/americas/ immigration.html; Julia Preston, Mexican Data Show Migration to U.S. in Decline, N.Y. Times, May 14, 2009, at A1.

171. See Marc R. Rosenblum, Migration Pol'y Inst., Obstacles and Opportunities for Regional Cooperation: The US.Mexico Case (2011), http://www.migrationpolicy.org/pubs/ USMexico-cooperation.pdf.

172. Id. (identifying these as four key challenges to bilateral migration accords, providing a historical overview of U.S.-Mexico migration, and concluding that U.S.-Mexico cooperation on migration is difficult but not impossible). 
repatriation. Looking to human rights laws and norms provides a way to hold the state accountable for inhumane practices such as medical repatriation and for analyzing the reciprocal duties that are owed to migrant laborers. 
- 